ISSN 1466-1535

\title{
FOR BETTER OR WORSE? NON-STANDARD JOBS AND HIGH INVOLVEMENT WORK SYSTEMS
}

SKOPE Research Paper No.29 Spring 2002

By Alan Felstead, University of Leicester and

Duncan Gallie, Nuffield College, Oxford

ESRC funded Centre on Skills, Knowledge and Organisational Performance Oxford and Warwick Universities 


\section{Editor's Foreword}

\section{SKOPE Publications}

This series publishes the work of the members and associates of SKOPE. A formal editorial process ensures that standards of quality and objectivity are maintained.

Orders for publications should be addressed to the SKOPE Secretary, SKOPE, Warwick Business School, University of Warwick, Coventry CV4 7AL. 


\title{
FOR BETTER OR WORSE? \\ NON-STANDARD JOBS AND HIGH INVOLVEMENT WORK SYSTEMS
}

\author{
Alan Felstead ${ }^{\dagger} \&$ Duncan Gallie ${ }^{\ddagger}$
}

May 2002

Centre for Labour Market Studies, University of Leicester.
ॠuffield College, Oxford.
Address for Correspondence:
Alan Felstead,
Centre for Labour Market Studies,
University of Leicester,
7-9 Salisbury Road,
Leicester LE1 7QR,
tel: +44 (0)116-252-5946;
fax: +44 (0)116-252-5953;
email: Alan.Felstead@le.ac.uk

The 2001 Skills Survey was funded through a contract between the UK Government's Department for Education and Skills and the Centre for Skills Knowledge and Organisational Performance (SKOPE) at the Universities of Oxford and Warwick. We are grateful to Ken Mayhew, the Director of SKOPE, for continued support and to Rosa Fernandez for research assistance. The full set of papers to be published within this contract are:

Dickerson, A.P. and. Green, F. (2002). The Growth and Valuation of Generic Skills. SKOPE Research Paper No. 26

Felstead, A. and Gallie, D. (2002) For Better or Worse? Non-Standard Jobs And High Involvement Work Systems. SKOPE Research Paper No. 29

Gallie, D., Felstead, A. and Green. F, (2002). Changing Patterns of Employee Involvement. SKOPE Research Paper No. 28

Green, F. and. Gallie, D. (2002) High Skills and High Anxiety: Skills, Hard Work and Mental Well-Being. SKOPE Research Paper No. 27

Green, F. and Mcintosh, S. (2002). Is there a Genuine Underutilisation of Skills. Amongst the Over-qualified?. SKOPE Research Paper No. 30

The report of the survey is published as:

Felstead, A., Gallie, D., and Green. F, (2002). Work Skills In Britain 1986-2001. Nottingham, DfES Publications. 


\section{SUMMARY}

This paper draws on data collected for the 2001 Skills Survey. It is, therefore, based on 4,005 employee responses - of whom, 907 were working part-time (less than 30 hours a week) and 248 were in temporary positions. The paper examines and compares their work skills and feelings of employment insecurity with full-time and permanent workers respectively. Our main findings are as follows:

- Whatever the measure and method of data analysis adopted, the jobs occupied by parttimers are less skilled than those occupied by full-timers. For example, part-timers regard a range of work activities - such as using a computer, dealing with people and spotting problems - as significantly less important to their jobs than full-timers do. This result applies to 35 out of 37 activities. A similar picture emerges from comparisons of the skills required to get and do jobs. Two-fifths of part-timers are in jobs that require no qualifications for entry compared to a fifth of full-timers. Seven out of ten part-timers are in jobs that require less than three months training time and a third say that their jobs can be learnt in less than one month. The proportions of full-timers claiming to be in a similar position are modest by comparison: around three-fifths and one-sixth respectively. Furthermore, once in post full-timers have more development opportunities than parttimers. A broadly similar, but less emphatic, picture of relative disadvantage emerges for the skills demanded by temporary jobs compared to permanent ones. So, for example, they are significantly less likely than permanent workers to be in a job where: their employer expects them to find better ways of carrying out their work; explicit development plans are outlined for individual workers; and future on-going training is expected.

- As far as employment insecurity is concerned, we do not find that part-time workers suffer from greater levels of uncertainty than full-timers. On the contrary, at the aggregate level we find that part-timers think it less likely that they will lose their jobs than full-timers. However, further analysis suggests that this may not due to part-time working per se, but may be more to do with the distribution of part-time jobs in the economy. For temporary workers, on the other hand, the likelihood of job loss is rated relatively highly - over two-fifths thought they might lose their job within a year compared to around one in seven permanent employees. This association remains even when other factors, such as the distribution of temporary jobs in the economy, are taken into account.

- We find a strong association between high involvement working - establishments that have open dialogue with workers, involve them in decision-making and give greater emphasis to teamworking - and the level of generic skills exercised by those employed. These environments make significant inroads into the skills gap between full-time and part-time jobs. This result holds for problem-solving, planning, peer communication and checking skills. Similarly, the temporary-permanent skills gap is significantly reduced in high involvement work environments for two out of four of these skills - problem-solving 
and checking. In addition, all workers - irrespective of their contractual status - benefit from the greater employment security these work environments provide.

These findings have a number of implications for policy-makers:

- Some of the recent changes in labour law aim to ensure that workers are treated equally whatever their contractual status. Many of these changes have been prompted by European Union Directives on non-standard employment covering part-timers, those on fixed-term contracts and will shortly also include temporary agency workers. Under the resulting new legislation, comparability will play a major role in adjudicating whether in fact non-standard workers have been unfairly treated. However, the lower skill content of these jobs is likely to reduce the number of successful claims since comparable jobs may be difficult to find.

- As from April 2003, employers will be obliged seriously to consider requests from working parents for reduced hours, rescheduled working patterns and/or a change in the location of their employment. It will be important for policy-makers to ensure that these new rights do not produce results that are at odds with the aims of the skills and inclusion agendas. Particular attention will need to be paid to ensuring that enhanced opportunities to work flexibly do not dampen the growth in skills overall nor increase the number of workers whose non-standard status is associated with relative disadvantage in terms of skills, development opportunities and employment security.

- The finding that high involvement workplaces demand higher skills of their employees as well as helping to close the skills gap between those on different employment contracts has an important implication for policy-makers. The Investors in People (IiP) programme promotes many of these practices and correlates very well with the more sophisticated measure of employee involvement at work used in the paper. This close association provides additional justification for policies designed to extend the reach of IiP, which is intended to promote best practice in skill development whatever the status, position or contractual basis on which employees work. 
FOR BETTER OR WORSE?

\section{NON-STANDARD JOBS AND HIGH INVOLVEMENT WORK SYSTEMS}

'Peripheral forms of employment such as temporary and part-time jobs ... entailed "intrinsic" or unavoidable shortcomings for workers; in particular, they tended to lack employment security. In addition, such jobs were inclined to require only low-level skills, and their peripheral status tended to inhibit investment in training from employers and workers in them were unlikely to enjoy substantial opportunities for advancement' (NEDO, 1986: 10).

\section{Introduction}

Organisational flexibility has gained increased importance in recent years. The ability to compete in many product markets is now tied to the speed with which an organisation can respond to consumer demand, tastes and preferences. A central feature of this agility is the flexibility and responsiveness of the workforce in the face of change. Two key aspects of organisational flexibility have gained prominence in academic, practitioner and policy-making circles. The first is numerical flexibility, that is the ability with which an organisation's 'headcount can be quickly and easily increased or decreased in line with even short term changes in the level of demand for labour' (Atkinson, 1984: 28). This can be achieved in a variety of ways. These include the use of additional or supplementary labour resources to meet changes in the level of output such as part-time, short-term contract or casual workers, and/or the alteration of existing working time arrangements such as varying the hours of part-timers, altering levels of overtime or changing shift patterns. The second is functional flexibility. This relates not to changes in the number of workers, but to changes in what they do. The aim here is to provide employees with multiple skills so they can adapt to change, be redeployed or take on new roles if shifting workloads, production methods and/or technology require it. Given their greater organisational attachment, it is presumed that full-time permanent workers provide this form of organisational flexibility.

Existing evidence suggests that both forms of flexibility are becoming more important aspects of modern day society. The traditional image of 'the job' is gradually being eroded; its open-ended nature, its temporal specificity and its fixed location no longer apply to large numbers of those in work. In particular, part-time work, self-employment and temporary work 
have begun to challenge traditional notions of what a job is comprised. To this list one can also add freelancing, subcontracting, franchising, homeworking, zero hours contracts, annualised hours, flexi-time contracts and many more. A common feature of all these forms of employment is that, in varying ways, they provide employers with the prospect of adjusting labour use to labour demand. In short, they offer numerical flexibility.

Taken together, part-timers, the self-employed and temporary workers account for approaching $40 \%$ of those in employment in Britain compared to $30 \%$ in the early $1980 \mathrm{~s}$ (Felstead et al., 1999; Hakim, 1987). Moreover, nearly three out of five women (59.0\%) and one in ten men $(11.2 \%)$ will work part-time at some point during their working lives. For temporary working, the equivalent figures are three out of ten (30.2\%) women and one in five men $(20.5 \%)$ (Dex and McCulloch, 1995: 91). In 2001, a quarter (24.9\%) of employees were in part-time work with a further one in fifteen (6.5\%) in temporary employment positions (National Statistics, 2001: Tables 12 and 13). Similar evidence can be cited for other parts of the developed world (see Felstead and Jewson, 1999). For example, estimates put the proportion of non-standard jobs in the US at around 30\% with temporary work quadrupling since the early 1980s (Kalleberg et al., 1997: 75; Rosenberg and Lapidus, 1999). This pattern is repeated elsewhere in North America. Canada has seen the number of non-standard jobs increase from $28 \%$ to $33 \%$ of jobs in the space of five years (Felstead et al., 1999: Table I). In some of the more regulated labour markets, particular types of non-standard work have grown while others have been kept in check. In Spain, for example, the growth of fixed-term contracts dwarfs the rise in self-employment and part-time working. Changes to Spanish employment legislation in 1993 permitted the operation of temporary employment agencies for the first time. This prompted a doubling of the number of workers on fixed-term contracts in less than a decade. It now represents one of the few ways in which employers can avoid the relatively high costs of hiring and firing standard workers (Cousins, 1999; see Smith, 2001 for an examination across the European Union). A similar motivation, it has been argued, lies behind the growth of non-standard jobs in Australia where they account for $45 \%$ of total employment (Burgess and Strachan, 1999).

Not only is the contractual nature of the job changing, but the nature of some employing organisations is also undergoing reformulation with important consequences for worker skills, 
training and employment security. Research has highlighted the decline of production systems based on hierarchical forms of control and Taylorist or Fordist management, and their replacement by work organisations that empower workers to participate in decision-making, encourage employees to work with their peers and enhance employee commitment to the organisation. This requires that workers gather information about the production process, interpret it and use it to guide future work activity. In other words, the system requires them to become functionally flexible. This new paradigm has been variously labelled with the most common including high involvement work systems (Edwards and Martin, 2001), high performance work organisations (Appelbaum et al., 2000; Osterman, 2000), flexible production systems (MacDuffie, 1995), high commitment systems (Walton, 1985), transformed work organisations (Osterman, 1995), alternative work practices (Gittleman et al., 1988) and high involvement management (Wood, 1999b). Although isolating the exact set of practices that make these organisations distinctive has occasioned a good deal of controversy, there is greater unanimity on the principles that underlie the concept (Wood, 1999a). Four can be identified: employee involvement in decision-making about the completion of immediate work tasks; feedback on work performance and opportunities for development; systems designed to reward performance and improve motivation; and mechanisms for sharing information and knowledge throughout the organisation (Ashton and Sung, 2002). These are in stark contrast to Taylorist management techniques in which - for all but the privileged few - jobs are strictly demarcated, job descriptions are tight, discretion is minimal, training is specific and contributions beyond completion of the work task are neither expected nor welcomed.

Survey evidence suggests that employee involvement is becoming extensive. For example, a recent survey carried out on behalf of the Chartered Institute of Personnel and Development in 2001 found that many aspects of high involvement working had taken root in British businesses (Guest and Conway, 2001). Almost two-fifths (38\%) of the workers questioned reported that programmes for employee involvement such as self-directed work teams or quality circles were in place, well over eight out of ten $(85 \%)$ said that their organisation kept them informed about how the business was doing, and three-quarters (76\%) said that their employer allowed them sufficient opportunity to express their views and raise concerns about their work on all or most occasions. Furthermore, surveys of establishments suggest that the use 
of these practices has been rising steadily in recent years. Comparison of management responses to the Workplace Employee Relations Survey in 1984, 1990 and 1998 suggest, for example, that regular circulation of newsletters or meetings between senior management and the workforce have both increased in prevalence - rising from just over a third of workplaces in 1984 to almost half in 1998. The proportion of workplaces where management provides information to employees on a range of matters (including the financial position of the establishment, investment plans and future staffing arrangements) has also risen, albeit from a smaller base of $20 \%$ in 1984 to $36 \%$ in 1998 . However, there remain a substantial minority of establishments where management divulges little information to its workforce - this has remained more or less constant over the 1984 to 1998 period at around 16\% (Millward et al., 1999: 229-232). A similar picture is evident in the US. For example, the National Survey of Establishments questioned a representative sample of private sector US establishments with 50 or more employees about a number of work arrangements in 1992 and then again in 1997. Respondents were asked what percentage of the largest group of employees at the establishment were involved in self-managed work teams, job rotation, quality circles or off-line problem-solving groups and Total Quality Management. The proportion of establishments with two or more practices in place covering at least half of the focus group doubled over the five year period - rising from a third of establishments (37.3\%) in 1992 to approaching three-quarters (71.4\%) in 1997 (Osterman, 2000: Table 2).

Nevertheless, despite sharing a common interest in organisational flexibility - albeit from different standpoints - the high involvement work literature and the non-standard employment literature have rarely crossed paths (see Kalleberg, 2001 for a review). One of the aims of this paper is to tackle this neglect by examining the interaction of the features of organisational and labour market change using data collected on 4,005 employees working in Britain in 2001. The paper, therefore, proceeds as follows. Section 2 considers existing evidence to support the proposition - rehearsed in the quotation at the top of the paper - that part-time and temporary workers occupy lower skilled positions, receive less training and are exposed to greater employment insecurity than those in full-time and permanent positions respectively. It also reviews existing material on the link that high involvement working has with skills, training and insecurity. Section 3 outlines the 2001 Skills Survey, the methods of data collection and the 
construction of the measures used in the empirical analyses that follow. The paper's substantive contribution is contained in the empirical results presented in Section 4. These comprise both bivariate comparisons and multivariate analyses on a wide range of skill measures and feelings of insecurity not readily available in many data sets. Using data from the 2001 Skills Survey, the paper addresses two research questions: are non-standard workers in lowly skilled and insecure jobs, and if so, does employment in high involvement workplaces make things better or worse? Section 5 concludes the paper with a summary of its main findings, policy implications and avenues for future research.

\section{Issues, Controversies and Testable Hypotheses}

\subsection{Non-Standard Jobs, Training, Skills and Insecurity}

It is commonly assumed that those in non-standard jobs are in low skilled positions, have limited training opportunities and are subject to greater levels of employment insecurity. A large amount of empirical evidence does exist to support each of these three assumptions. However, the evidence is often incomplete, contested and is not always up-to-date. The evidence is reviewed briefly below. From this, a number of testable hypotheses emerge.

Both sides of industry have frequently raised concerns that employers may be less prepared to train their part-time, and in particular, temporary staff than their full-time and permanent employees. As a result, the training non-standard workers receive may be minimal and superficial (CBI, 1994; TUC, 1995). Some research evidence confirms such fears. For example, using data from the first five waves of the British Household Panel Survey (BHPS), Arulampalam and Booth (1998) find that workers on short-term contracts or working part-time are significantly less likely to be involved in any work-related training to improve or increase their skills. To be precise, their results show that ceteris paribus a man on a temporary or fixedterm contract is $16 \%$ less likely to receive training in his current job than a man on a permanent contract. For a woman a temporary contract reduces the likelihood of her receiving training by $12 \%$ on what a female employee on a permanent contract, but in otherwise identical circumstances, could expect. The results for part-time working suggest that men are $7 \%$ less likely to receive training than men who work full-time, while women in part-time work are $9 \%$ 
less likely than their full-time counterparts to be training recipients. This analysis has been extended to cover the 1991-1997 period with similar results (Booth et al., 2000). However, an objection to these striking findings is that the research does not test whether the results hold for any given period of paid work. This may alter the findings for temporary workers in particular since analysis of the Labour Force Survey (LFS) suggests that average training times vary considerably - in 1997 permanent employees got an average of 37 minutes off-the-job training per week compared to 59 minutes for those on fixed-term contracts and 49 minutes for casual or seasonal workers (Green, 1999). In other words, while the overall incidence of training for temporary workers is lower than it is for permanent workers, this may reflect the fact that temporary workers have shorter job tenures and are therefore more likely to require 'frontloaded' (induction) training of above average length.

Despite this controversy, other research tends to confirm the stereotypical view that parttime and temporary workers do poorly in terms of access to training opportunities. Rix et al. (1999) use a range of techniques - including analysis of data from the LFS, and interviews with national representative organisations, sector bodies, managers in 21 companies and a sample of 166 employees - to come to this conclusion. Using these multiple techniques, they find that nonstandard workers record lower rates of training participation, receive task-specific rather than general or industry-specific bouts of training and are expected to arrive ready-skilled if on a temporary engagement in the higher occupational groups.

A second commonly held assumption is that those in non-standard jobs are in low skilled positions. Their educational credentials, occupational group and, sometimes, industrial location provide some evidence for this proposition (Warren, 2000). Firmer evidence, however, comes from studies of what jobs require on entry and what they comprise. For example, previous analyses of the Social Change and Economic Life Initiative (SCELI) survey carried out in 1986 have focused on the job demands of particular types of non-standard worker. This shows that part-time work, on average, requires lower qualifications, shorter periods of training and can be learnt relatively quickly. It also shows that particular job demands are less important in part-time work than full-time work. This includes work experience, organisational knowledge, talent for the type of work and technical or scientific knowledge. However, part-time work differs little 
from full-time work in terms of the importance placed on personal and social relationships with colleagues and clients (Horrell et al., 1994). This analysis has been updated with evidence drawn from the Employment in Britain (EIB) survey carried out in 1992 and has produced similar results (Gallie et al., 1998: 154-159). However, a comparative dimension has also been added. This suggests that while part-timers remain at a severe disadvantage, their position has improved rather than deteriorated between 1986 and 1992. Temporary working, too, has been the subject of investigation using EIB data. This shows that although differences do emerge between the skill position of temporary workers and their permanent colleagues, these evaporate when a limited set of controls is introduced. Nevertheless, the data suggest that temporary workers experienced a more rapid increase in job demands relative to their permanent counterparts (ibid: 174-176).

However, in previous surveys only a limited number of skills specific questions were asked of respondents since the scope of these surveys was broad and covered a wide range of other issues, including household relationships, work histories, experience of unemployment, trade union attitudes and socio-political values. The 2001 Skills Survey and its 1997 predecessor have, as their name implies, a more limited focus which allows them to provide a fuller picture of the skills content of jobs occupied by respondents. Previous analysis of the 1997 Skills Survey data suggests that both part-timers and temporary workers are in less skilled jobs (Felstead et al., 2001). However, the sample sizes on which some of this analysis is based are small, especially in the case of temporary working, where standard errors are large and consequently significance levels for bivariate comparisons are difficult to reach. These difficulties are minimised in the case of the 2001 Skills Survey, which comprises almost double the number of employee respondents $(2,195$ versus 4,005$)$. In addition, we report on a number of new questions relating to the opportunities employees have to engage in workplace learning as well as providing a more up-to-date picture. Furthermore, we subject the data to more rigorous tests.

The third assumption surrounding non-standard jobs is aptly captured in some of the alternative labels authors have used to describe this type of work: 'precarious', 'disposable', 'contingent' and 'peripheral'. The idea here is that these workers can be more readily hired and fired than full-time permanent workers, notwithstanding employment protection. Most of the 
evidence for this assumption is taken from analysis of job tenure rates, that is the length of time individuals spend with their employer. This consistently shows that part-time jobs and temporary jobs are associated with lower job tenure than full-time permanent positions. Gregg and Wadsworth (1995: 80) conclude on the basis of a panel analysis of the LFS that full-time jobs last just over six years, part-time jobs for about half as long and temporary jobs typically for just ten months. Similar findings emerge from analyses carried out by other authors using different data sets and different techniques (Burgess and Rees, 1996; Dex and McCulloch, 1997; Gregg et al., 2000; Booth et al., 2000).

Although job tenure is one indicator of insecurity, there are others too. One of these is to get respondents to assess the ease with which they could be dismissed in a number of hypothetical situations such as being dismissed within a month for not working hard enough or persistently arriving late. This approach was adopted in EIB. The results show that part-time workers are no more insecure than full-timers. However, employees on contracts lasting less than a year felt particularly exposed to rapid dismissal (Gallie et al., 1998: Tables 6.10 and 6.18). Other measures of insecurity tend to emphasise the subjective aspect of the phenomenon such as how secure people feel their job is and how easily they feel they would be able to get another job without 'trading down' in the labour market (Burchell et al., 2002). It is on this aspect of insecurity that respondents to the Skills Surveys were asked to express a view. However, the differential impact of insecurity according to employment type has only been incidentally examined in previous analysis of variations in patterns of insecurity over time (Green et al., 2000).

\subsection{High Involvement Work Systems, Training, Skills and Insecurity}

While there is a large volume of existing empirical evidence linking non-standard employment with training, skills and insecurity, the empirical evidence linking high involvement work systems with these intermediate outcomes is thinner on the ground. Instead much of the debate revolves around whether these types of organisations do better or worse than others in delivering high performance outcomes as measured by productivity, sales per employee, operating profits and/or inventory levels (eg, MacDuffie, 1995; Batt, 1999; Wood, 1999b; 
Cappelli and Neumark, 2001). Nevertheless, a number of studies are noteworthy for the purposes of this paper.

The link high involvement working has with training has received more emphasis than skills or insecurity. This is mainly because training is easier to measure at the establishment level where most of the relevant data have so far been collected. For example, the Osterman (1995) study is based on a telephone survey conducted in 1992 among a sample of 875 business establishments in the US. These data reveal a positive association between companies using high involvement work systems - such as team production, job rotation, quality circles and Total Quality Management - and the incidence of formal off-the-job training among the establishment's largest occupational group. Other studies have come to much the same conclusion despite using different data sets, defining high involvement working slightly differently and being carried out in different countries (eg, MacDuffie, 1995; MacDuffie and Kochan, 1995; Whitfield, 2000).

Nevertheless, many authors end by speculating on the content of the training and the skills most associated with high involvement work systems. MacDuffie and Kochan (1995), for example, conclude by suggesting that high involvement workplaces are more likely to demand cognitive and interpersonal skills - such as problem-solving, teamworking and communication than technical skills. Similarly, Appelbaum et al. (2000: 206-210) outline a similar set of worker skills that high involvement working is expected to deliver. However, this is based on theoretical and fieldwork observations rather than quantitative evidence since a survey of workers' skills was not carried out. Corroborative evidence of the existence of such a link is hinted at in studies of learning (eg, Eraut et al., 1998a and 1998b), which identify environments most conducive to the development of these types of skills. According to this evidence, these skills are enhanced when employees are involved in organising, planning and/or checking the quality of their own work. This may be through teams that have their own responsibilities and are given the freedom to determine how work is organised (Benders et al., 1999), or through individuals given the autonomy to organise their own work tasks, pace and standards. Either way, problems have to be resolved as and when they arise, and the solutions communicated to fellow colleagues. The solutions found will be more effective in enhancing organisational performance when knowledge 
about the production process and the organisation's prospects is widely known, and effective feedback mechanisms are in place. By asking respondents to the 2001 Skills Survey about organisational practices as well as their involvement in decision-making and how work is organised, we are able to offer a distinctive contribution to this debate. This builds on previous analysis of the 1997 Skills Survey that suggested a link between one element of high involvement working - namely, organisational practices - and the skills identified above (Felstead and Ashton, 2000; Green et al., 2001).

Finally, for some researchers job security is a crucial element of the high involvement work system since for them it is characterised by three elements - employee involvement, continuous training and security of employment (eg, Brown et al., 1993). Each element mutually reinforces the other two. Employment security raises employee involvement since workers are more willing to make suggestions for improvements when their jobs and those of others are less at risk. In addition, employment security raises the incentives for employee and employer to invest in training since the odds are that the employment relationship will persist. At the same time, training raises employment security since higher trained workers become more adaptable and flexible, and better equipped to make contributions in the context of employee involvement. The need for training is, in turn, enhanced by employee involvement since it highlights the importance of situated learning and increases employees' interest in learning new skills. Greater involvement also enhances employment security as higher productivity and high quality output make the organisation more competitive. The suggestion, therefore, is that employment security will be far higher in high involvement organisations than elsewhere.

For the purposes of this paper, the implicit assumption in much of this literature is that employment in a high involvement work setting is of equal benefit to all workers, including parttimers and those on temporary contracts. This is the basis of four of eight hypotheses we set out to test. 


\subsection{Hypotheses}

From the above, eight hypotheses can be tested using the 2001 Skills Survey. These are formally stated as follows:

- H1: Part-time employees are in less skilled jobs than those on full-time contracts.

- H2: Part-time employees are exposed to greater insecurity than those on full-time contracts.

- H3: Temporary employees are in less skilled jobs than those on permanent contracts.

- H4: Temporary employees are exposed to greater insecurity than those on permanent contracts.

- H5: Employment in a high involvement workplace neither privileges nor disadvantages the skills of part-time employees as compared to those on full-time contracts.

- H6: Employment in a high involvement workplace neither privileges nor disadvantages the employment security of part-time employees as compared to those on full-time contracts.

- H7: Employment in a high involvement workplace neither privileges nor disadvantages the skills of temporary employees as compared to those permanent contracts.

- H8: Employment in a high involvement workplace neither privileges nor disadvantages the employment security of temporary employees as compared to those permanent contracts.

\section{Data Source, Measures and Methods}

\section{Data Source}

The results reported in this paper are based on data collected as part of the 2001 Skills Survey. This is a large-scale, cross-sectional, representative sample survey of individuals aged between 20 and 60 in Britain who were in paid work at the time of interview. The survey contains interviews with 4,470 individuals, 4,005 of whom were working as employees. Households and eligible interviewees were selected randomly and interviews were carried out in the period of February-June 2001, with nine out of ten interviews taking place in March, April and May. Sample weights were computed to take into account the differential probabilities of sample selection according to the number of dwelling units at each issued address and the number of eligible interview respondents. Further analysis on the representativeness of the achieved sample was carried out after the fieldwork was complete. The distribution of the 
achieved sample was compared with the Spring 2001 Labour Force Survey - carried out in the months of March, April and May - according to age, ethnicity, working time, occupation and industry. The two distributions were found to be acceptably close. However, sex weights were added to the sample weights, in order to correct for a slight under-representation of men in the sample. All of the bivariate analyses that follow are weighted accordingly. The results are therefore based on a high quality, randomly drawn and representative data set (further detail in Felstead et al., 2002a).

\section{Measures}

The focus of this paper is on non-standard forms of employment and in particular, parttime jobs and temporary contracts. Given their centrality, it is worth spelling out in detail how each is measured by the survey and how their prevalence in the data set compares to estimates based on larger samples such as the Spring 2001 LFS. As with the LFS, part-time working is defined according to the responses given to the question: 'How many hours per week do you usually work?' Those who report working less than 30 hours per week are deemed to be parttimers, while those working 30 hours or more per week are deemed to be working full-time. On this basis, just over a fifth (21.3\%) of those questioned for the 2001 Skills Survey work part-time, the majority of whom are women (85.6\%). Remarkably, this reflects exactly the proportion estimated to be working part-time according to equivalent questions in the Spring 2001 LFS (see Table 1). However, the gender breakdown suggests that the 2001 Skills Survey over-represents the number of male part-timers by a couple of percentage points, while under-estimating the number of female part-timers by an equivalent margin. Nevertheless, the distribution of parttime jobs across the economy as suggested by the 2001 Skills Survey is broadly in line with the pattern in the LFS. Both suggest that part-time jobs are more prevalent in the public sector, in industries such as hotels and restaurants, retailing and education, and in occupations such as personal services and sales. 
TABLE 1:

EXTENT OF PART-TIME AND TEMPORARY WORKING IN BRITAIN, 2001

\begin{tabular}{|c|c|c|}
\hline Non-Standard Jobs & 2001 Skills Survey & $\begin{array}{c}\text { Spring 2001 Labour Force } \\
\text { Survey }\end{array}$ \\
\hline $\begin{array}{l}\text { Part-time }(<30 \text { hours per } \\
\text { week })^{1} \\
\text { Of which: }\end{array}$ & 21.3 & 21.3 \\
\hline $\begin{array}{l}\text { Women } \\
\text { Men }\end{array}$ & $\begin{array}{l}85.8 \\
14.2\end{array}$ & $\begin{array}{l}87.7 \\
12.3\end{array}$ \\
\hline $\begin{array}{l}\text { Temporary }{ }^{2} \\
\text { Of which: }\end{array}$ & 6.2 & 6.0 \\
\hline $\begin{array}{l}\text { Women } \\
\text { Men }\end{array}$ & $\begin{array}{l}54.7 \\
45.3\end{array}$ & $\begin{array}{l}55.2 \\
44.8\end{array}$ \\
\hline
\end{tabular}

Notes:

1. Part-time jobs are defined as those held by employees who usually work less than 30 hours per week. These data are taken from the 'How many hours per week do you usually work?' question in the 2001 Skills Survey, and the equivalent questions in the Spring 2001 Labour Force Survey (TOTUS1 and USUHR variables). Reassuringly, the self-definition question in both surveys yields similar proportions of respondents who consider themselves parttimers $(21.0 \%$ in the Skills Survey and $22.3 \%$ in the Labour Force Survey).

2. Temporary jobs were identified in both surveys using a virtually identical question. Respondents are asked: 'Leaving aside your own personal intentions and circumstances, is [was in LFS] your job ... a permanent job or, is [was] there some way that it is [was] NOT permanent?'

3. The 2001 Skills Survey data reported here and in the bivariate analyses that follow are weighted by a factor that takes into account the slight over-representation of women in all of the samples and according to the number of eligible respondents at each address visited. All calculations exclude missing values. The Spring 2001 Labour Force Survey is weighted by the INTWT grossing factor. For comparability these estimates are restricted to individuals aged 20-60 years old who were in paid work in Britain at the time of the interview.

Source: 2001 Skills Survey and Spring 2001 Labour Force Survey. 'Put Table 1 about here'

The pattern for temporary jobs is similarly close. These jobs are identified by both surveys through a virtually identically worded question. Respondents were asked: 'Leaving aside your own personal intentions and circumstances, is [was in LFS] your job ... a permanent job or, is [was] there some way that it is [was] NOT permanent?' According to this question both the 2001 Skills Survey and the LFS for the equivalent period yield an estimate of around $6 \%$ of 
employees who consider their job as temporary in some way. The gender breakdowns are also very close with both estimating that women account for a slight majority of all temporary positions. In addition, the distribution of temporary jobs in the samples are reasonably close temporary jobs are more prevalent in the public sector, in industries such as education, health and business services, and in professional and personal service occupations.

Several features of high involvement work systems are well recognised by most authors in the field. The 2001 Skills Survey contains data on most of these features. Nevertheless, it is important to recall at the onset that our unit of observation is the individual employee rather than a management respondent. This ensures that we get a more accurate measure of whether certain work practices are experienced by individual employees in the workplace rather than relying on management's estimates of their prevalence (cf. Osterman, 1995). However, while our unit of observation may reduce measurement error in this way, pitching our questions at individual employees inevitably limits the organisational information we were usefully able to collect. Nevertheless, we did ask a total of four questions on organisational practices, which form part of our high involvement work index (see below). The four are whether: respondents belong to a group of employees which regularly meets to discuss organisational improvements (QC); there is a formal appraisal system at the workplace (APPRAISE); management organises meetings to inform the workforce of organisational developments (INFORM); and management holds meetings where workers can express their views and opinions (EXPRESS).

In addition, respondents were asked to assess how much personal influence they have over specific aspects of their work: how hard to work, deciding what tasks to do, how the task is to be done, and the quality standards to achieve. Respondents were given a range of options from which to choose: 'a great deal', 'a fair amount', 'not much' and 'none at all'. To provide a picture of personal task discretion from these items, a summary index is constructed by giving a score ranging from 0 ('none at all') to 3 ('a great deal') to each of the four aspects of work and then taking the average of the summed scores (DISCRETION). This produces a statistically robust index with a Cronbach's Alpha of 0.77. Another aspect of employee involvement in decisions about their job is captured elsewhere in the questionnaire. Respondents were asked: 'Suppose there was going to be some decision at your place of work that changed the way you do 
your job. Do you think that you personally would have any say in the decision about the change or not?' Those answering 'yes' were then asked how much of a say they thought they would have. Three options were given: 'a great deal', 'quite a lot' and 'just a little'. From this, an index of personal influence in decision-making is derived, ranging from 0 (where there is no say) to 3 (where employees report that they would have a great deal of influence in the decision) (PARTIC).

Another aspect of high involvement working is team production. Respondents were asked whether they usually worked with other employees in a similar position. Those who answered 'yes' were asked a series of questions about the influence the work group had over four specific aspects of their work: its pace, content, methods and standards. The options given ranged from 'a great deal' to 'none at all'. Scores of 0-3 are awarded according to the amount of influence the work group has over each aspect of work with a 0 indicating 'none at all' and 3 indicating 'a great deal'. By taking an average of the summed scores a team influence index is then derived (TEAMIND). This produces a statistically robust index with a Cronbach's Alpha of 0.85. Additionally, respondents were asked to assess the importance of teamworking in their jobs. Their answers were recorded on a five-point scale (TWORK).

Each of the eight elements of high involvement working identified above is given a standardised score (mean 0 and standard deviation 1), so that all the elements have equal weight in the high involvement work index (HIWIND). By taking an average of the summed standardised scores, the HIWIND variable is derived. Tests of internal consistency suggest that the index captures a reasonable level of correlation between the separate items (Cronbach's Alpha $=0.67$ ). However, inclusion of another aspect of high involvement working - performance related pay whether tied to respondents, work groups, workplaces or organisations - reduces the alpha statistic a couple of points. We have, therefore, decided to exclude performance-related pay from the HIWIND variable. However, the pattern of results outlined below is not sensitive to this decision. 
Subsequent factor analysis of these variables suggests a three-factor solution: company policies load most heavily on QC, EXPRESS, INFORM and APPRAISE; direct involvement in task decisions loads mostly on DISCRETION and PARTIC; and group involvement of peers is related to TEAMIND and TWORK. The explanatory importance of these three groups is, therefore, considered in some of the analysis that follows. Elsewhere, we take each dimension of involvement and seek to identify workplace and employee characteristics most closely associated with each dimension (Gallie et al., 2002).

The abilities demanded by different jobs vary enormously. To capture this diversity both the 2001 and the 1997 Skills Surveys included questions on a wide range of different job activities. Respondents were asked: 'in your job, how important is [a particular job activity]'. Examples of the activities included 'caring for others', 'dealing with people', 'using a computer', 'analysing complex problems' and 'planning the activities of others'. The questionnaire covered 37 activities designed to span the tasks carried out in a wide range of jobs. The response scale ranged from 'essential' to 'not at all important', with 'very important', 'fairly important' and 'not very important' in between. It is also worth pointing out that those respondents who reported that their job involved 'using a computer, PC or other types of computerised equipment' were asked to indicate their level of computer usage. The response options were 'straightforward', 'moderate', 'complex' and 'advanced'. Each option was accompanied by a set of examples.

The analysis which follows adopts the following approach: scores are awarded to each respondent according to how important each activity is in their job - the higher the score, the more important the skill. Scores of 4, 3, 2, 1 and 0 respectively are allocated according to an individual's response, so that those responding 'not at all important' score 0 whereas those reporting the activity to be 'essential' score 4. The figures reported here refer to the average Skill Scores and hence they summarise the entire distribution of responses to each activity question.

To reduce the data into a smaller number of manageable and interpretable factors for subsequent analysis, the non-computing items are transformed into a scale running from 0 ('not at all important') to 4 ('essential'). Then, using factor analysis, ten generic skill measures are generated. The factors that emerge are chosen in such a way as to capture sub-sets of variables 
that vary closely with one another and conform to theoretical concepts of generic skill types. Ten factors emerge from this analysis (for detail see Dickerson and Green, 2002; Felstead et al., 2002a). Of particular relevance to the focus of this paper are the following four types of generic skill since they have most relevance to high involvement working: problem-solving (detecting, diagnosing, analysing and resolving problems); checking (noticing and checking for errors); peer communication (working with a team of people and listening carefully to colleagues); and planning (planning activities, organising one's own time and thinking ahead). These generic skill measures are standardised to give an average of zero and standard deviation of one. As a result, any negative score indicates that the skill is being used less than average, and vice versa. In each case, the score is based on all the variables in the analysis, but the description above (and in Table 3) indicates those activities that contribute most to the determination of each factor.

The Skills Surveys (like SCELI and EIB before them) also measure the skills required to get and do jobs as measured by qualifications, length of training and time taken to learn to do the job well. Most of the data on these matters are self-explanatory and clear-cut since they report proportions of people who say they would need a qualification at a particular level to get their current job, the length of training required for the type of work they now do and the length of time needed to do their job well. To summarise this information, indices are derived with scales designed to capture the complete distribution of responses (see Table 4).

Respondents were also asked to describe aspects of their job that affected their obligation or opportunity to learn and make improvements. Thus, respondents were asked: 'Does your employer expect you to find better ways of doing your job?' and whether they agreed with the statement: 'My job requires that I keep learning new things'. They were also asked about formal training opportunities such as whether they had a written document setting out their future jobrelated learning, training or education and whether they thought their employer would provide ongoing training for them in the future.

Of final relevance to the focus of this paper is the measurement of insecurity. A total of three questions were asked of respondents to the Skills Surveys (the same ones were also asked of SCELI respondents). One asked respondents: 'Do you think that there is any chance at all of 
your losing your job and becoming unemployed in the next twelve months?' Those who answered 'yes' were asked: 'How would you rate the likelihood of this happening?' Respondents were given a choice of five options ranging from 'very likely' to 'very unlikely' and were asked to select one from a show card. By using information from these two questions we construct a measure of the extent to which a respondent thinks that his/her current job will endure. This ranges from those who think that there is no chance at all of them losing their job through to those who think that such a scenario is 'very likely'. By allocating scores of 0 to 5 to each of these scenarios, we derive a job loss likelihood index with higher values indicating a greater expectation of job loss. The third question asked respondents: 'If you were looking for work today, how easy or difficult do you think it would be for you to find a job as good as your current one?' Four options were offered on a show card - 'very easy', 'quite easy', 'quite difficult' and 'very difficult' - respondents were asked to choose one. We allocate a score of 1 to those who think it would be 'very easy', 2 if they report it as 'quite easy', 3 if they estimate that it would be 'quite difficult' and 4 if they think it would be 'very difficult' to get another job as good as their current one. The resulting scores indicate the cost of job loss to individuals. From this another measure of insecurity is possible - one which combines both the likelihood of job loss and the difficulty of changing employers without experiencing a deterioration in terms and conditions of employment. To construct such an index, we simply multiply the cost of job loss by the likelihood of such an event happening.

\section{Methods}

Two main methods of data analysis are adopted. First, we compare the skills and security of jobholders according to working time (full-time versus part-time) and type of contract (permanent versus temporary). While these bivariate comparisons may be robust in the face of a number of standard statistical tests, they are only the first step in any thorough analysis. Moreover, the two-way comparisons fail to provide even weak tests for the hypotheses that seek to examine whether non-standard jobholders are better or worse off when they are in a high involvement work environment. Multivariate analysis of some of the key relationships - the second method adopted in this paper - is subject to none of these drawbacks. 


\section{Results}

The paper addresses two related questions to emerge from the literature briefly reviewed in Section 2. Are non-standard jobs lowly skilled and insecure and, if so, do high involvement work environments make things better or worse? The presentation of the results in this section is divided accordingly.

\subsection{Are Non-Standard Jobs Lowly Skilled and Insecure?}

Only rarely have respondents been asked about the particular abilities their jobs demand and, even then, only a limited number of abilities have been covered. The SCELI evidence, for example, relates to one area and is based on just six questions (13 in the case of the employer survey), EIB contains five questions of relevance and cohort studies - such as the British Cohort Study and the National Child Development Study - measure the abilities that individuals possess rather than those demanded by the jobs (Horrell et al., 1989 and 1994; Burchell et al., 1994; Bynner, 1994; Gallie and White, 1993: 25; White, 1999: 49-51).

A significant contribution of the Skills Surveys has been the collection of data on a wide range of activities involved in the paid work individuals carry out. Table 2 compares the skills content of full-time jobs with part-time ones and permanent jobs with temporary ones in 2001 according to 37 activities and the sophistication of computer use. On only three occasions do part-timers significantly out-score full-timers, with two of these revolving around the establishment of social and personal relationships at work (dealing with people and caring for others). For the remaining 35 activities, part-timers occupy lower skilled jobs than full-timers. Moreover, these differences are highly significant for all activities apart from manual abilities such as the need for physical stamina and dexterity. Additional analysis shows the full-time/parttime dichotomy hides further differences according to the number of hours worked. So, for example, those working less than 16 hours a week occupy the lowest skilled jobs, while those working more than 44 hours a week are at the other end of the scale, occupying the highest skilled jobs according to most of our particular skills measures. However, the importance of 
computer use and the level of sophistication vary substantially either side of the 30 hours dichotomy.

The evidence on the permanent versus temporary comparison is, on the face of it, equally compelling (see Table 2). This suggests that permanent employees are, on average, in significantly more demanding jobs than those on temporary contracts with respect to virtually all the activities about which respondents were questioned. However, computing skills are one of the aspects of work where the differences fail to reach a reasonable level of statistical significance. Nevertheless, even in this case, permanent employees report higher (if not significantly so) computing skill demands than their temporary counterparts. Temporary employees were also asked to specify in what way they felt their job to be temporary. From the responses, it is possible to divide temporary jobs into those considered to be fixed-term and those working on a more uncertain basis as casual, seasonal or agency workers. Despite the small numbers involved (4.3\% and $1.8 \%$ of the sample respectively), some interesting contrasts emerge. For almost half of the activities, those on fixed-term contracts record similar - albeit mostly lower - importance ratings to those on open-ended permanent contracts, while casual/seasonal/agency workers are in the least demanding jobs according to all the particular measures except those relating to manual skills. However, according to the remaining activity measures, temporary workers on fixed-term contracts are in jobs that are more demanding than those held by their temporary counterparts on casual/seasonal/agency terms, but less demanding than those in permanent positions. 
TABLE 2:

SKILL CONTENT OF JOBS BY WORKING TIME AND PERMANENCY, 2001

\begin{tabular}{|c|c|c|c|c|}
\hline \multirow{2}{*}{$\begin{array}{l}\text { Skill Content } \\
\text { of Jobs }\end{array}$} & \multicolumn{4}{|c|}{ Skills Scores ${ }^{1}$} \\
\hline & Full-Time & Part-Time & Permanent & Temporary \\
\hline \multicolumn{5}{|l|}{ Communication and Social Skills } \\
\hline Dealing with people $^{2}$ & 3.31 & $3.39 *$ & 3.34 & $3.09 * * *$ \\
\hline Instructing, training or teaching people & 2.49 & $2.22 * * *$ & 2.46 & $2.11 * * *$ \\
\hline Making speeches or presentations & 1.36 & $0.90 * * *$ & 1.27 & 1.11 \\
\hline Persuading or influencing others & 2.27 & $1.71 * * *$ & 2.18 & $1.76 * * *$ \\
\hline Selling a product or service & 1.64 & $1.44 * * *$ & 1.66 & $0.73 * * *$ \\
\hline $\begin{array}{l}\text { Counselling, advising or caring for } \\
\text { customers or clients }\end{array}$ & 2.49 & $2.62 * *$ & 2.53 & $2.21 * * *$ \\
\hline \multicolumn{5}{|l|}{ Teamworking Skills } \\
\hline Working with a team of people & 3.17 & $2.98 * * *$ & 3.14 & $2.98 * *$ \\
\hline Listening carefully to colleagues & 3.20 & $3.04 * * *$ & 3.18 & $2.99 * * *$ \\
\hline Cooperating with colleagues & 3.39 & $3.20 * * *$ & 3.37 & $3.16^{* * *}$ \\
\hline \multicolumn{5}{|l|}{ Manual Skills } \\
\hline Physical strength & 1.55 & $1.71 * * *$ & 1.59 & $1.42 *$ \\
\hline Physical stamina & 1.84 & 1.80 & 1.85 & $1.57 * * *$ \\
\hline $\begin{array}{l}\text { Skill or accuracy in using hands or } \\
\text { fingers }\end{array}$ & 2.12 & 2.04 & 2.11 & 2.10 \\
\hline \multicolumn{5}{|l|}{ Knowledge Skills } \\
\hline $\begin{array}{l}\text { How to use or operate } \\
\text { tools/equipment/machinery }\end{array}$ & 2.45 & $2.13 * * *$ & 2.40 & $2.09 * * *$ \\
\hline $\begin{array}{l}\text { Knowledge of particular products or } \\
\text { services }\end{array}$ & 2.87 & $2.42 * * *$ & 2.81 & $2.21 * * *$ \\
\hline Specialist knowledge or understanding & 3.14 & $2.59 * * *$ & 3.04 & $2.75 * * *$ \\
\hline $\begin{array}{l}\text { Knowledge of how your organisation } \\
\text { works }\end{array}$ & 2.88 & $2.52 * * *$ & 2.82 & $2.50 * * *$ \\
\hline \multicolumn{5}{|l|}{ Computing Skills } \\
\hline $\begin{array}{l}\text { Using a computer, PC, or other types of } \\
\text { computerised equipment }\end{array}$ & 2.63 & $1.95 * * *$ & 2.49 & 2.33 \\
\hline Level of computer usage $^{3}$ & 1.72 & $1.06^{* * *}$ & 1.58 & 1.57 \\
\hline \multicolumn{5}{|l|}{ Problem-Solving Skills } \\
\hline Spotting problems or faults & 3.27 & $2.88 * * *$ & 3.21 & $2.83 * * *$ \\
\hline $\begin{array}{l}\text { Working out the causes of problems or } \\
\text { faults }\end{array}$ & 3.06 & $2.56 * * *$ & 2.99 & $2.48 * * *$ \\
\hline $\begin{array}{l}\text { Thinking of solutions of problems or } \\
\text { faults }\end{array}$ & 3.06 & $2.52 * * *$ & 2.97 & $2.57 * * *$ \\
\hline Analysing complex problems in depth & 2.29 & $1.54 * * *$ & 2.16 & $1.69 * * *$ \\
\hline
\end{tabular}




\begin{tabular}{|c|c|c|c|c|}
\hline \multicolumn{5}{|l|}{$\begin{array}{l}\text { Table } 2 \text { continued } \\
\text { Checking Skills }\end{array}$} \\
\hline $\begin{array}{l}\text { Checking things to ensure that there are } \\
\text { no errors }\end{array}$ & 3.23 & $2.83 * * *$ & 3.16 & $2.89 * * *$ \\
\hline Noticing when there is a mistake & 3.35 & $2.97 * * *$ & 3.28 & $3.02 * * *$ \\
\hline Paying close attention to detail & 3.54 & $3.33^{* * *}$ & 3.51 & $3.32 * * *$ \\
\hline \multicolumn{5}{|l|}{ Planning Skills } \\
\hline Planning your own activities & 2.97 & $2.42 * * *$ & 2.87 & $2.59^{* * *}$ \\
\hline Planning the activities of others & 1.95 & $1.35^{* * *}$ & 1.84 & $1.52^{* * *}$ \\
\hline Organising your own time & 3.07 & $2.61 * * *$ & 2.99 & $2.80 * *$ \\
\hline Thinking ahead & 3.16 & $2.68^{* * *}$ & 3.07 & $2.88^{* *}$ \\
\hline \multicolumn{5}{|l|}{ Reading Skills } \\
\hline $\begin{array}{l}\text { Reading written information such as } \\
\text { forms notices or signs }\end{array}$ & 3.09 & $2.70^{* * *}$ & 3.02 & $2.77 * * *$ \\
\hline $\begin{array}{l}\text { Reading short documents such as short } \\
\text { reports, letters or memos }\end{array}$ & 2.91 & $2.48^{* * *}$ & 2.84 & $2.56^{* * *}$ \\
\hline $\begin{array}{l}\text { Reading long documents such as long } \\
\text { reports, manuals, articles or books }\end{array}$ & 2.33 & $1.80^{* * *}$ & 2.24 & $1.95 * * *$ \\
\hline \multicolumn{5}{|l|}{ Writing Skills } \\
\hline $\begin{array}{l}\text { Writing written information such as } \\
\text { forms notices or signs }\end{array}$ & 2.54 & $2.09^{* * *}$ & 2.45 & $2.25 * *$ \\
\hline $\begin{array}{l}\text { Writing short documents such as short } \\
\text { reports, letters or memos }\end{array}$ & 2.50 & $1.79^{* * *}$ & 2.37 & $2.15^{* *}$ \\
\hline $\begin{array}{l}\text { Writing long documents such as long } \\
\text { reports, manuals, articles or books }\end{array}$ & 1.83 & $1.21 * * *$ & 1.71 & $1.55^{*}$ \\
\hline \multicolumn{5}{|l|}{ Numeracy Skills } \\
\hline $\begin{array}{l}\text { Adding, subtracting or dividing } \\
\text { numbers }\end{array}$ & 2.52 & $1.93 * * *$ & 2.42 & $2.03 * * *$ \\
\hline $\begin{array}{l}\text { Calculations using decimals } \\
\text { percentages or fractions }\end{array}$ & 2.12 & $1.40^{* * *}$ & 1.99 & $1.70^{* * *}$ \\
\hline $\begin{array}{l}\text { Calculations using more advanced } \\
\text { mathematical or statistical procedures }\end{array}$ & 1.34 & $0.76^{* * *}$ & 1.24 & $0.94 * * *$ \\
\hline
\end{tabular}

\section{Notes:}

1. Each respondent was asked to indicate how important particular activities were in their jobs. The response scale was as follows: 'Essential/Very important/Fairly important/Not very important/Not at all important'. Scores of 4, 3, 2, 1 and 0 respectively were allocated to an individual's response, so that those responding 'Not at all important' scored 0 whereas those reporting the activity to be 'Essential' scored 4. Higher Skills Scores denote more skilled job content. The figures reported here refer to the average Skill Scores given for each column.

2. T-tests were carried out on the mean differences between full-time and part-time jobs (columns 1 against 2), and between permanent and temporary jobs (columns 3 and 4). The results are shown against the mean scores in columns 2 and 4 respectively. Here $* * *=99 \%$ significant, $* *=95 \%$ significant and $*=90 \%$ significant.

3. If 'using a computer, PC, or other types of computerised equipment' was part of their job, each respondent was asked to indicate their level of computer use. Four options were given ranging from 'straightforward' through 'moderate' and 'complex' to 'advanced'. Each was accompanied by a set of concrete examples. To measure the level of computer usage, non-users were given a score of 0 while users were given scores of 1,2,3 or 4 according to their level of computer use. The figures reported here refer to the level of computer usage given for each column.

Source: 2001 Skills Survey. 
Comparisons of the ten generic skills that emerge from factor analysis yield a similar story (see Table 3 ). In nine out of ten cases (the exception being physical skills), part-timers and temporary workers occupy significantly lower skilled jobs than their respective counterparts. It is important to note that this applies to the skills most associated with high involvement working problem-solving, checking, peer communication and planning (the first four rows of Table 3). However, the comparative standing of part-timers versus full-timers and temporary workers versus permanent workers according to these generic skills is neither better nor worse than for other skills such as numeracy that have little explicit connection with high involvement systems.

TABLE 3:

GENERIC SKILLS USED AT WORK BY WORKING TIME AND PERMANENCY, 2001

\begin{tabular}{|l|c|c||c|c|}
\hline \multirow{2}{*}{$\begin{array}{c}\text { Generic Skills } \\
\text { Used at Work }\end{array}$} & \multicolumn{3}{c|}{ Factor Skills Scores } \\
\cline { 2 - 5 } & Full-Time & Part-Time & Permanent & Temporary \\
\hline Problem-Solving & 0.15 & $-0.37^{* * *}$ & 0.07 & $-0.37^{* * *}$ \\
\hline Checking & 0.14 & $-0.27^{* * *}$ & 0.07 & $-0.23^{* * *}$ \\
\hline Peer Communication & 0.14 & $-0.13^{* * *}$ & 0.10 & $-0.18^{* * *}$ \\
\hline Planning & 0.13 & $-0.38^{* * *}$ & 0.04 & $-0.24^{* * *}$ \\
\hline Literacy & 0.16 & $-0.29^{* * *}$ & 0.08 & $-0.15^{* * *}$ \\
\hline Physical & -0.06 & $0.06^{* * *}$ & -0.03 & -0.10 \\
\hline Numeracy & 0.14 & $-0.36^{* * *}$ & 0.05 & $-0.21^{* * *}$ \\
\hline Technical Know-How & 0.12 & $-0.31^{* * *}$ & 0.05 & $-0.31^{* * *}$ \\
\hline High Level Communication & 0.13 & $-0.34^{* * *}$ & 0.05 & $-0.17^{* * *}$ \\
\hline Client Communication & 0.03 & $-0.12^{* * *}$ & 0.02 & $-0.37^{* * *}$ \\
\hline
\end{tabular}

Notes:

1. These generic skills emerge from factor analysis reported more fully elsewhere (Dickerson and Green, 2002; Felstead et al., 2002a). Factor loadings suggest the following interpretation of the ten factors: problem-solving (detecting, diagnosing, analysing and resolving problems); checking (noticing and checking for errors); peer communication (working with a team of people and listening carefully to colleagues); planning (planning activities, organising one's own time and thinking ahead); literacy (both reading and writing forms, notices, memos, signs, letters, short and long documents; physical (the use of physical strength and/or stamina); numeracy (adding, 
subtracting, divisions, decimal point or fraction calculations and/or more advanced maths or statistical procedures); technical know-how (knowing how to use tools or equipment or machinery, knowing about products and services, specialist knowledge and/or skill in using one's hands); high-level communication (top-down communication skills, including persuading or influencing others, instructing, training or teaching people, making speeches or presentations and writing long reports; this factor is also linked to the importance of analysing complex problems in depth); and client communication (selling a product or service and counselling or caring for customers or clients).

\section{Source: 2001 Skills Survey.}

The 2001 Skills Survey also allows us to compare the skills required of different types of worker to get and do their jobs. For example, the qualifications required of respondents to get their current job vary significantly between full-timers and part-timers. Almost two-fifths (39.8\%) of part-timers are in jobs that require no qualifications for entry compared to just over one-fifth $(21.9 \%)$ of full-timers. This is also reflected at the upper end of the qualifications hierarchy where one in every three (32.5\%) full-timer claims that a level 4 or above qualification is required to get their current job compared to around one in five (18.5\%) part-timers (see Table 4). The summary required qualification index is equally emphatic: on average, full-timers are in jobs that require at least a level 2 qualification (2.29 on the index), whereas part-timers' jobs have significantly lower entry requirements with possession of a level 1 qualification being sufficient in most cases (1.50 on the index). Other indicators of job requirements suggest much the same. For example, seven out of ten $(70.7 \%)$ part-timers are in jobs that require less than three months training time and a third (37.4\%) say their jobs can be learnt in less than one month. The proportions of full-timers claiming to be in a similar position are modest by comparison: around three-fifths $(57.8 \%)$ and one-sixth $(15.6 \%)$ respectively. Full-timers also maintain their advantage in terms of skill development opportunities: better ways of doing the job are an integral part of $79.3 \%$ of full-timers' jobs compared to $62.7 \%$ of those occupied by part-timers; $84.3 \%$ of full-timers are in jobs that require on-going learning compared to $70.4 \%$ of part-time jobs; $24.9 \%$ of full-timers compared to $17.8 \%$ of part-timers have a written career or training plan; and $76.3 \%$ versus $67.7 \%$ of full-timers and part-timers respectively report that their employer has a commitment to their on-going training. All these differences are statistically significant and suggest that once in post, full-timers have more development opportunities than part-timers. 
TABLE 4:

SKILLS REQUIRED AND DEVELOPMENT OPPORTUNTIES BY WORKING TIME AND PERMANENCY, 2001

\begin{tabular}{|c|c|c|c|c|}
\hline \multirow{2}{*}{$\begin{array}{c}\text { Skills and } \\
\text { Development } \\
\text { Opportunities }\end{array}$} & \multicolumn{2}{|c|}{ Weekly Hours of Work } & \multicolumn{2}{|c|}{ Permanency of Employment } \\
\hline & Full-Time & Part-Time & Permanent & Temporary \\
\hline \multicolumn{5}{|c|}{ (a) Highest Qualification Required ${ }^{1}$} \\
\hline Level 4 or above & 32.5 & $18.5^{* * *}$ & 29.1 & $36.3^{*}$ \\
\hline Level 3 & 18.5 & $7.8 * * *$ & 16.5 & 13.2 \\
\hline Level 2 & 16.1 & 18.4 & 16.7 & 15.2 \\
\hline Level 1 & 11.0 & $15.5^{* * *}$ & 12.0 & 12.0 \\
\hline None & 21.9 & $39.8^{* * *}$ & 25.8 & 23.4 \\
\hline $\begin{array}{l}\text { Required } \\
\text { Qualification } \\
\text { Index }\end{array}$ & 2.29 & $1.50 * * *$ & 2.11 & 2.27 \\
\hline \multicolumn{5}{|l|}{ (b) Training Time $e^{2}$} \\
\hline$>2$ years & 25.7 & $15.6^{* * *}$ & 23.5 & 24.1 \\
\hline$<3$ months & 57.8 & $70.7 * * *$ & 60.5 & 62.4 \\
\hline $\begin{array}{l}\text { Training } \\
\text { Index }\end{array}$ & 2.44 & $1.74 * * *$ & 2.30 & 2.15 \\
\hline \multicolumn{5}{|l|}{ (c) Learning Time ${ }^{3}$} \\
\hline$>2$ years & 28.8 & $13.6^{* * *}$ & 26.1 & $18.1 * * *$ \\
\hline$<1$ month & 15.6 & $37.4 * * *$ & 19.2 & $35.2 * * *$ \\
\hline $\begin{array}{l}\text { Learning } \\
\text { Index }\end{array}$ & 3.80 & $2.71 * * *$ & 3.62 & $2.87 * * *$ \\
\hline \multicolumn{5}{|c|}{ (d) Development Opportunities } \\
\hline $\begin{array}{l}\text { Finding Better } \\
\text { Ways of Doing the } \\
\text { Job }^{4}\end{array}$ & 79.3 & $62.7 * * *$ & 76.8 & $61.5 * * *$ \\
\hline $\begin{array}{l}\text { Job Requires } \\
\text { Learning }^{5}\end{array}$ & 84.3 & $70.4 * * *$ & 81.6 & 77.1 \\
\hline $\begin{array}{l}\text { Written Career or } \\
\text { Training Plan }^{6}\end{array}$ & 24.9 & $17.8 * * *$ & 24.1 & $12.9 * * *$ \\
\hline $\begin{array}{l}\text { Future On-Going } \\
\text { Training by } \\
\text { Employer }^{7}\end{array}$ & 76.3 & $67.7 * * *$ & 77.1 & $52.2 * * *$ \\
\hline
\end{tabular}


Notes:

1. Respondents were asked: 'If they were applying today, what qualifications, if any, would someone need to get the type of job you have now?' A range of options was given. From this the highest qualification level, ranked by NVQ equivalents, was derived. An index was calculated from the responses: none $=0$; level 1=1; level 2=2; level $3=3$; and level 4 or above $=4$. For 2001, the following qualification mapping was applied: Level 4 and above $=$ masters or PhD degree, university or CNAA degree, other professional (eg, law, medicine), teaching, nursing (eg SCM, RGN, SRN, SEN) NVQ level 4 (or SNVQ4) or HNC/HNC (or SHNC/SHNC); Level 3 = GCE 'A' level or GNVQ advanced, SCE higher or SLC/SUPE higher, certificate of $6^{\text {th }}$ year studies, university certificate/diploma (not degree), SCOTVEC national certificate, SCOTBEC/SCOTBEC certificate/diploma, completion of trade apprenticeship, NVQ level 3 (or SNVQ 3) or ONC/OND (or SNC/SND); Level 2 = GCSE A*-C or GNVQ intermediate or GCE 'O' level or CSE grade 1 or school certificate of matriculation, SCE standard (1-3)/ordinary (A-C) or SLC/SUPE lower, clerical/commercial (eg typing or bookkeeping), professional qualification without sitting exam, NVQ level 2 (or SNVQ 2); Level 1 = GCSE D-G or CSE (other than grade 1) or GNVQ foundation, other, NVQ level 1 (or SNVQ 1); No qualifications $=$ none reported.

2. Respondents were asked: 'Since completing full-time education, have you ever had, or are you currently undertaking, training for the type of work that you currently do?' Respondents answering 'yes' were then asked: 'How long, in total, did (or will) that training last?' A range of options was given. An index was calculated from the responses: none $=0$; less than 1 month $=1 ; 1=3$ months $=2 ; 3-6$ months $=3 ; 6-12$ months $=4 ; 1-2$ years $=5$; and over 2 years $=6$.

3. Respondents were asked: 'How long did it take for you after you first started doing this type of job to learn to do it well?' An index was calculated from the responses: less than 1 month=1; less than 3 months $=2 ; 3-6$ months $=3$; 6-12 months $=4 ; 1-2$ years $=5$; and over 2 years $=6$.

4. Respondents were asked: 'Does your employer expect you to take responsibility for finding better ways of doing the job?'.

5. Respondents were asked to indicate how much they agreed or disagreed with the following statement: 'My job requires that I keep learning new things'. The options were: strongly agree, agree, disagree or strongly disagree. The percentages reported here refer to the extent to which respondents agreed or strongly agreed with the statement.

6. Respondents were asked: 'Do you have a written career or training plan at work, that is, a written document that sets out your future job-related learning, training or education?'.

7. Respondents were asked: 'Do you think your employer will provide on-going training for you in the future?'.

$*=$ a statistically significant difference between full-time and part-time jobs, and permanent and temporary jobs $(\mathrm{p}<0.10)$

** = a statistically significant difference between full-time and part-time jobs, and permanent and temporary jobs $(\mathrm{p}<0.05)$

$* * *=$ a statistically significant difference between full-time and part-time jobs, and permanent and temporary jobs $(\mathrm{p}<0.01)$

The comparative fortunes of temporary employees and those on permanent contracts are less clear-cut (see Table 4). Both in terms of the qualifications required for jobs and the training needed to carry them out, the differences between these groups are small. In fact, the only significant difference (if only at the $10 \%$ level) is in the proportions reporting they would need a level 4 or above qualification to get their current job. Surprisingly, this suggests that a greater proportion of temporary positions than permanent ones require high-level qualifications for entry. The most likely explanation for these findings are the marked differences between fixed-term and casual/seasonal/agency workers, with the relatively high required skill level of the former cancelling out the relatively low required skill level of the latter. For example, the required qualification index for temporary workers as a whole is 2.27 , a level higher than for permanent 
workers (though not statistically significant). However, this figure conceals considerable variation, with a low of 1.60 for casual/seasonal/agency workers and a high of 2.57 for those on fixed-term contracts. The same goes for the training index: 2.15 for temporary workers as a whole, but a low of 1.55 for casual/seasonal/agency workers and a high of 2.37 for those employed on fixed-term contracts. However, the learning time evidence suggests that temporary workers as a whole are in significantly less skilled jobs than permanent workers. In other words, on average, their jobs are quicker to learn, taking less than a month in a third (35.2\%) of cases compared to a fifth (19.2\%) of permanent jobs. Access to development opportunities also suggests that temporary workers are in a more disadvantaged position. They are significantly less likely than permanent workers to be in a job where: their employer expects them to find better ways of carrying out their work; explicit development plans are outlined for individual workers; and future on-going training is expected.

In contrast, to the skills data we find little evidence to suggest that part-timers are in more insecure jobs than full-timers (see Table 5). In fact, the data reveal that part-timers are, if anything, in more secure employment positions than full-timers. Only 14\% of part-timers thought there was a chance they might lose their job in the twelve months after interview. This is significantly lower than $18 \%$ of full-timers who thought likewise. When asked about the likelihood of this happening, part-timers were significantly more optimistic about retaining their current job. They were also significantly more upbeat about being able to secure a job of similar standing were they to lose their job and as a result, they were exposed to significantly lower levels of risk associated with job loss. 
TABLE 5:

INSECURITY BY WORKING TIME AND PERMANENCY OF EMPLOYMENT, 2001

\begin{tabular}{|l|c|c||c|c|}
\hline \multirow{2}{*}{ Insecurity } & \multicolumn{2}{|c||}{ Weekly Hours of Work } & \multicolumn{2}{c|}{ Permanency of Employment } \\
\cline { 2 - 5 } & Full-Time & Part-Time & Permanent & Temporary \\
\hline $\begin{array}{l}\text { Any Chance of } \\
\text { Losing Job }\end{array}$ & 0.18 & $0.14^{*}$ & 0.15 & $0.44^{* * *}$ \\
\hline $\begin{array}{l}\text { Likelihood of } \\
\text { Job Loss }\end{array}$ & 0.57 & $0.48^{* *}$ & 0.48 & $1.63^{* * *}$ \\
\hline $\begin{array}{l}\text { Risk of Job } \\
\text { Loss }\end{array}$ & 1.60 & $1.27^{* *}$ & 1.35 & $4.27^{* * *}$ \\
\hline
\end{tabular}

\section{Notes:}

1. Respondents were asked: 'Do you think that there is any chance at all of your losing your job and becoming unemployed in the next twelve months?'

2. Those who answered 'yes' to the above were asked: 'How would you rate the likelihood of this happening?' Respondents were given a choice of five options: 'very likely', 'quite likely', 'evens', 'quite unlikely' and 'very unlikely'. By allocating scores of 0 to 5 to these states we derive a likely job loss index with higher values indicating a greater expectation of job loss.

3. Respondents were also asked: 'If you were looking for work today, how easy or difficult do you think it would be for you to find a job as good as your current one?' Four options were offered on a show card - 'very easy', 'quite easy', 'quite difficult' and 'very difficult' - respondents were asked to choose one. We allocate a score of 1 to those who think it would be 'very easy', 2 if they report it as 'quite easy', 3 if they estimate that it would be 'quite difficult' and 4 if they think it would be 'very difficult' to get another job as good as their current one. The resulting scores indicate the cost of job loss to individuals. This is multiplied by the likelihood of such an event happening to derive a risk of job loss index.

Source: 2001 Skills Survey.

The same cannot be said for temporary workers who according to all our indicators are in less secure employment. Their chances of job loss are significantly higher than those employed on permanent contracts $-44 \%$ thought they might lose their job within a year after being interviewed compared to $15 \%$ of permanent employees. This is reflected in a significantly higher likelihood of job loss rating. These differences are so great that they overwhelm the relative ease with which temporary workers report it would be for them to get a similar job in the external labour market. The result is that temporary workers shoulder very high levels of risk of job loss, 
significantly higher than those on permanent contracts. Moreover, this pattern is repeated for each of the different categories of temporary worker on which we have data.

\subsection{Do High Involvement Work Systems Make Things Better or Worse?}

The use of multivariate analysis allows us to substantiate further these bivariate findings and examine whether working in a high involvement environment makes things better or worse. While it is not the focus of this paper to examine the distribution of these practices in the economy - nor would such an analysis be wholly appropriate given that our information is gathered from individual workers not managers - some notable patterns provide useful background to what follows. Levels of employee involvement are positively correlated with workplace size, are highest in the public sector and are lowest in industries such as construction, transport, wholesale and retail, and hotels and restaurants.

To answer the research question posed by the paper (and explicitly spelt out in the title to this sub-section), we focus on the skills the literature suggests are most associated with high involvement working - problem-solving, checking, planning and peer communication skills (see Tables 6-9). For each of these generic skills, we examine the relationship it has with part-time jobs, temporary jobs and high involvement working (Model 1) after controlling for occupation, industry, gender, qualifications and so on (see Table 6 for a complete list). The high involvement work index is then interacted with part-time jobs and temporary working and these are entered into each regression (Model 2). Finally, the three key aspects of the high involvement work index are entered separately and as interaction terms in order to isolate which aspect has more explanatory power (Model 3). 
TABLE 6:

PROBLEM-SOLVING SKILLS USED AT WORK, NON-STANDARD JOBS AND HIGH INVOLVEMENT WORK SYSTEMS, 2001

\begin{tabular}{|c|c|c|c|}
\hline & Model 1 & Model 2 & Model 3 \\
\hline \multicolumn{4}{|l|}{ (a) Non-Standard Jobs } \\
\hline Part-Time Job & $\begin{array}{l}-0.2111 * * * \\
(0.0393)\end{array}$ & $\begin{array}{l}-0.1869 * * * \\
(0.0385)\end{array}$ & $\begin{array}{l}-0.1826 * * * \\
(0.0382)\end{array}$ \\
\hline Temporary Job & $\begin{array}{l}-0.2061 * * * \\
(0.0645)\end{array}$ & $\begin{array}{l}-0.1630^{* * *} \\
(0.0616)\end{array}$ & $\begin{array}{l}-0.1800 * * * \\
(0.0637)\end{array}$ \\
\hline \multicolumn{4}{|c|}{ (b) High Involvement Work Systems } \\
\hline $\begin{array}{l}\text { High Involvement } \\
\text { Work Index }\end{array}$ & $\begin{array}{l}0.5419 * * * \\
(0.0285)\end{array}$ & $\begin{array}{l}0.4647 * * * \\
(0.0315)\end{array}$ & -- \\
\hline $\begin{array}{l}\text { High Involvement } \\
\text { Work Index and Part- } \\
\text { Time Jobs }\end{array}$ & -- & $\begin{array}{l}0.2660^{* * *} \\
(0.0640)\end{array}$ & -- \\
\hline $\begin{array}{l}\text { High Involvement } \\
\text { Work Index and } \\
\text { Temporary Jobs }\end{array}$ & -- & $\begin{array}{r}0.2085^{*} \\
(0.1180)\end{array}$ & -- \\
\hline \multicolumn{4}{|c|}{ (c) Features of High Involvement Work Systems } \\
\hline Company Policies & -- & -- & $\begin{array}{l}0.0864 * * * \\
(0.0218)\end{array}$ \\
\hline Task Involvement & -- & -- & $\begin{array}{l}0.1821 * * * \\
(0.0185)\end{array}$ \\
\hline Group Involvement & -- & -- & $\begin{array}{l}0.2443 * * * \\
(0.0202)\end{array}$ \\
\hline $\begin{array}{l}\text { Company Policies \& } \\
\text { Part-Time Jobs }\end{array}$ & -- & -- & $\begin{array}{c}0.0580 \\
(0.0464)\end{array}$ \\
\hline $\begin{array}{l}\text { Task Involvement \& } \\
\text { Part-Time Jobs }\end{array}$ & -- & -- & $\begin{array}{l}0.0849 * * \\
(0.0401)\end{array}$ \\
\hline $\begin{array}{l}\text { Group Involvement \& } \\
\text { Part-Time Jobs }\end{array}$ & -- & -- & $\begin{array}{l}0.1513 * * * \\
(0.0452)\end{array}$ \\
\hline $\begin{array}{l}\text { Company Policies \& } \\
\text { Temporary Jobs }\end{array}$ & -- & -- & $\begin{array}{c}0.0825 \\
(0.0850)\end{array}$ \\
\hline $\begin{array}{l}\text { Task Involvement \& } \\
\text { Temporary Jobs }\end{array}$ & -- & -- & $\begin{array}{c}0.0568 \\
(0.0860)\end{array}$ \\
\hline $\begin{array}{l}\text { Group Involvement \& } \\
\text { Temporary Jobs }\end{array}$ & -- & -- & $\begin{array}{c}0.0673 \\
(0.0789)\end{array}$ \\
\hline \multicolumn{4}{|l|}{ (d)Model Parameters } \\
\hline Controls & Yes & Yes & Yes \\
\hline R Squared & 0.2637 & 0.2696 & 0.2958 \\
\hline $\begin{array}{l}\text { Number of } \\
\text { Observations }\end{array}$ & 3745 & 3745 & 3745 \\
\hline
\end{tabular}




\section{Notes:}

1. This table reports the regression results for each column. Model 1 reports the basic model comprising two dummy variables for part-time jobs and temporary jobs, the high involvement work index (see text), and a range of control variables. The latter consist of dummy variables for gender, unionised workplace, public sector, four establishment size categories, two workplace gender composition indicators, eight occupational groups, four levels of qualification held and twelve industrial groups. Age and age squared of respondents are entered as continuous variables. Model 2 adds two interaction terms to Model 1 in order to indicate whether or not the relationship non-standard working has with skills used at work is modified by the presence of high involvement work practices, and if so in what way. Model 3 isolates three key aspects of high involvement working and interacts each of them with part-time and temporary working. The same controls are also entered.

2. White-corrected standard errors are shown in parentheses. These are used in preference to conventional estimates of variance in order to provide robust tests of significance in the presence of heteroskedasticity.

3. $* * *=99 \%$ significant; $* *=95 \%$ significant; $*=90 \%$ significant.

Source: 2001 Skills Survey. 
TABLE 7:

PLANNING SKILLS USED AT WORK, NON-STANDARD JOBS AND HIGH INVOLVEMENT WORK SYSTEMS, 2001

\begin{tabular}{|c|c|c|c|}
\hline & Model 1 & Model 2 & Model 3 \\
\hline \multicolumn{4}{|l|}{ (a) Non-Standard Jobs } \\
\hline Part-Time Job & $\begin{array}{l}-0.2842 * * * \\
(0.0361)\end{array}$ & $\begin{array}{l}-0.2644 * * * \\
(0.0353)\end{array}$ & $\begin{array}{l}-0.2588 * * * \\
(0.0339)\end{array}$ \\
\hline Temporary Job & $\begin{array}{l}-0.1335 * * \\
(0.0575)\end{array}$ & $\begin{array}{l}-0.1226^{* *} \\
(0.0547)\end{array}$ & $\begin{array}{l}-0.1265 * * \\
(0.0527)\end{array}$ \\
\hline \multicolumn{4}{|c|}{ (b) High Involvement Work Systems } \\
\hline $\begin{array}{l}\text { High Involvement } \\
\text { Work Index }\end{array}$ & $\begin{array}{l}0.6136 * * * \\
(0.0257)\end{array}$ & $\begin{array}{l}0.5591 * * * \\
(0.0287)\end{array}$ & -- \\
\hline $\begin{array}{l}\text { High Involvement } \\
\text { Work Index and Part- } \\
\text { Time Jobs }\end{array}$ & -- & $\begin{array}{l}0.2108 * * * \\
(0.0554)\end{array}$ & -- \\
\hline $\begin{array}{l}\text { High Involvement } \\
\text { Work Index and } \\
\text { Temporary Jobs }\end{array}$ & -- & $\begin{array}{c}0.0551 \\
(0.1089) \\
\end{array}$ & -- \\
\hline \multicolumn{4}{|c|}{ (c) Features of High Involvement Work Systems } \\
\hline Company Policies & -- & -- & $\begin{array}{l}0.1203 * * * \\
(0.0204)\end{array}$ \\
\hline Task Involvement & -- & -- & $\begin{array}{l}0.3111 * * * \\
(0.0178)\end{array}$ \\
\hline Group Involvement & -- & -- & $\begin{array}{l}0.1798 * * * \\
(0.0185)\end{array}$ \\
\hline $\begin{array}{l}\text { Company Policies \& } \\
\text { Part-Time Jobs }\end{array}$ & -- & -- & $\begin{array}{l}0.0822 * * \\
(0.0419)\end{array}$ \\
\hline $\begin{array}{l}\text { Task Involvement \& } \\
\text { Part-Time Jobs }\end{array}$ & -- & -- & $\begin{array}{r}0.0599 * \\
(0.0368) \\
\end{array}$ \\
\hline $\begin{array}{l}\text { Group Involvement \& } \\
\text { Part-Time Jobs }\end{array}$ & -- & -- & $\begin{array}{l}0.0877 * * \\
(0.0368)\end{array}$ \\
\hline $\begin{array}{l}\text { Company Policies \& } \\
\text { Temporary Jobs }\end{array}$ & -- & -- & $\begin{array}{l}-0.0455 \\
(0.0724)\end{array}$ \\
\hline $\begin{array}{l}\text { Task Involvement \& } \\
\text { Temporary Jobs }\end{array}$ & -- & -- & $\begin{array}{c}0.0593 \\
(0.0684) \\
\end{array}$ \\
\hline $\begin{array}{l}\text { Group Involvement \& } \\
\text { Temporary Jobs }\end{array}$ & -- & -- & $\begin{array}{c}0.0420 \\
(0.0757) \\
\end{array}$ \\
\hline \multicolumn{4}{|l|}{ (d)Model Parameters } \\
\hline Controls & Yes & Yes & Yes \\
\hline R Squared & 0.4004 & 0.4032 & 0.4328 \\
\hline $\begin{array}{l}\text { Number of } \\
\text { Observations }\end{array}$ & 3745 & 3745 & 3745 \\
\hline
\end{tabular}

Note:

As for Table 6.

Source: 2001 Skills Survey. 
TABLE 8:

PEER COMMUNICATION SKILLS USED AT WORK, NON-STANDARD JOBS AND HIGH INVOLVEMENT WORK SYSTEMS, 2001

\begin{tabular}{|c|c|c|c|}
\hline & Model 1 & Model 2 & Model 3 \\
\hline \multicolumn{4}{|l|}{ (a) Non-Standard Jobs } \\
\hline Part-Time Job & $\begin{array}{l}-0.1293^{* * *} \\
(0.0304)\end{array}$ & $\begin{array}{l}-0.1092 * * * \\
(0.0292)\end{array}$ & $\begin{array}{l}-0.1029 * * * \\
(0.0269)\end{array}$ \\
\hline Temporary Job & $\begin{array}{l}-0.0839 * \\
(0.0507)\end{array}$ & $\begin{array}{l}-0.0751 \\
(0.0468)\end{array}$ & $\begin{array}{l}-0.1162 * * \\
(0.0444)\end{array}$ \\
\hline \multicolumn{4}{|c|}{ (b) High Involvement Work Systems } \\
\hline $\begin{array}{l}\text { High Involvement } \\
\text { Work Index }\end{array}$ & $\begin{array}{l}0.7899^{* * *} \\
(0.0229)\end{array}$ & $\begin{array}{l}0.7354 * * * \\
(0.0253)\end{array}$ & -- \\
\hline $\begin{array}{l}\text { High Involvement } \\
\text { Work Index and Part- } \\
\text { Time Jobs }\end{array}$ & -- & $\begin{array}{l}0.2128 * * * \\
(0.0516)\end{array}$ & -- \\
\hline $\begin{array}{l}\text { High Involvement } \\
\text { Work Index and } \\
\text { Temporary Jobs } \\
\end{array}$ & -- & $\begin{array}{c}0.0450 \\
(0.0999) \\
\end{array}$ & -- \\
\hline \multicolumn{4}{|c|}{ (c) Features of High Involvement Work Systems } \\
\hline Company Policies & -- & -- & $\begin{array}{l}0.1495^{* * *} \\
(0.0166)\end{array}$ \\
\hline Task Involvement & -- & -- & $\begin{array}{l}0.1522 * * * \\
(0.0149)\end{array}$ \\
\hline Group Involvement & -- & -- & $\begin{array}{l}0.5110^{* * * *} \\
(0.0147)\end{array}$ \\
\hline $\begin{array}{l}\text { Company Policies \& } \\
\text { Part-Time Jobs }\end{array}$ & -- & -- & $\begin{array}{c}0.0595^{*} \\
(0.0337) \\
\end{array}$ \\
\hline $\begin{array}{l}\text { Task Involvement \& } \\
\text { Part-Time Jobs }\end{array}$ & -- & -- & $\begin{array}{c}0.0383 \\
(0.0315) \\
\end{array}$ \\
\hline $\begin{array}{l}\text { Group Involvement \& } \\
\text { Part-Time Jobs }\end{array}$ & -- & -- & $\begin{array}{l}0.1092 * * * \\
(0.0338)\end{array}$ \\
\hline $\begin{array}{l}\text { Company Policies \& } \\
\text { Temporary Jobs }\end{array}$ & -- & -- & $\begin{array}{c}0.0418 \\
(0.0584)\end{array}$ \\
\hline $\begin{array}{l}\text { Task Involvement \& } \\
\text { Temporary Jobs }\end{array}$ & -- & -- & $\begin{array}{l}-0.0094 \\
(0.0570)\end{array}$ \\
\hline $\begin{array}{l}\text { Group Involvement \& } \\
\text { Temporary Jobs }\end{array}$ & -- & -- & $\begin{array}{c}0.0283 \\
(0.0579)\end{array}$ \\
\hline \multicolumn{4}{|l|}{ (d)Model Parameters } \\
\hline Controls & Yes & Yes & Yes \\
\hline R Squared & 0.4280 & 0.4315 & 0.5339 \\
\hline $\begin{array}{l}\text { Number of } \\
\text { Observations }\end{array}$ & 3745 & 3745 & 3745 \\
\hline
\end{tabular}

Note:

As for Table 6.

Source: 2001 Skills Survey. 
TABLE 9:

CHECKING SKILLS USED AT WORK, NON-STANDARD JOBS AND HIGH INVOLVEMENT WORK SYSTEMS, 2001

\begin{tabular}{|c|c|c|c|}
\hline & Model 1 & Model 2 & Model 3 \\
\hline \multicolumn{4}{|l|}{ (a) Non-Standard Jobs } \\
\hline Part-Time Job & $\begin{array}{l}-0.1991 * * * \\
(0.0404)\end{array}$ & $\begin{array}{l}-0.1706^{* * *} \\
(0.0398)\end{array}$ & $\begin{array}{l}-0.1678 * * * \\
(0.0376)\end{array}$ \\
\hline Temporary Job & $\begin{array}{l}-0.1313 * * \\
(0.0660)\end{array}$ & $\begin{array}{l}-0.0821 \\
(0.0645)\end{array}$ & $\begin{array}{l}-0.1113 \\
(0.0696)\end{array}$ \\
\hline \multicolumn{4}{|c|}{ (b) High Involvement Work Systems } \\
\hline $\begin{array}{l}\text { High Involvement } \\
\text { Work Index }\end{array}$ & $\begin{array}{l}0.3239^{* * *} \\
(0.0293)\end{array}$ & $\begin{array}{l}0.2337 * * * \\
(0.0317)\end{array}$ & -- \\
\hline $\begin{array}{l}\text { High Involvement } \\
\text { Work Index and Part- } \\
\text { Time Jobs }\end{array}$ & -- & $\begin{array}{l}0.3121 * * * \\
(0.0701)\end{array}$ & -- \\
\hline $\begin{array}{l}\text { High Involvement } \\
\text { Work Index and } \\
\text { Temporary Jobs }\end{array}$ & -- & $\begin{array}{r}0.2380^{*} \\
(0.1304)\end{array}$ & -- \\
\hline \multicolumn{4}{|c|}{ (c) Features of High Involvement Work Systems } \\
\hline Company Policies & -- & -- & $\begin{array}{c}0.0252 \\
(0.0223)\end{array}$ \\
\hline Task Involvement & -- & -- & $\begin{array}{l}0.0762 * * * \\
(0.0193)\end{array}$ \\
\hline Group Involvement & -- & -- & $\begin{array}{l}0.1619^{* * * *} \\
(0.0204)\end{array}$ \\
\hline $\begin{array}{l}\text { Company Policies \& } \\
\text { Part-Time Jobs }\end{array}$ & -- & -- & $\begin{array}{c}0.0602 \\
(0.0499)\end{array}$ \\
\hline $\begin{array}{l}\text { Task Involvement \& } \\
\text { Part-Time Jobs }\end{array}$ & -- & -- & $\begin{array}{l}0.1099 * * \\
(0.0435)\end{array}$ \\
\hline $\begin{array}{l}\text { Group Involvement \& } \\
\text { Part-Time Jobs }\end{array}$ & -- & -- & $\begin{array}{l}0.1759 * * * \\
(0.0494)\end{array}$ \\
\hline $\begin{array}{l}\text { Company Policies \& } \\
\text { Temporary Jobs }\end{array}$ & -- & -- & $\begin{array}{c}0.1284 \\
(0.0858)\end{array}$ \\
\hline $\begin{array}{l}\text { Task Involvement \& } \\
\text { Temporary Jobs }\end{array}$ & -- & -- & $\begin{array}{l}-0.0038 \\
(0.0928)\end{array}$ \\
\hline $\begin{array}{l}\text { Group Involvement \& } \\
\text { Temporary Jobs }\end{array}$ & -- & -- & $\begin{array}{c}0.1105 \\
(0.0818)\end{array}$ \\
\hline \multicolumn{4}{|l|}{ (d)Model Parameters } \\
\hline Controls & Yes & Yes & Yes \\
\hline R Squared & 0.1452 & 0.1537 & 0.1714 \\
\hline $\begin{array}{l}\text { Number of } \\
\text { Observations }\end{array}$ & 3745 & 3745 & 3745 \\
\hline
\end{tabular}

Note:

As for Table 6.

Source: 2001 Skills Survey. 
These results confirm that part-time jobs and temporary jobs are significantly less demanding than full-time and permanent positions respectively. The part-time coefficient is negative and significant in all three models and across all four generic skills. The picture for temporary jobs is not quite as emphatic since on three out of twelve occasions the temporary coefficient - although negative - fails to reach levels of statistical significance (see Panel (a), Tables 8 and 9).

The analysis also confirms the strong association that high involvement working has with the level of skills exercised by those employed in these workplaces. The high involvement work index is positive and significantly related to problem-solving, planning, peer communication and checking skills - without exception, the high involvment work coefficient is highly significant, surpassing the $1 \%$ level with ease (see Panel (b), Tables 6-9). For the most part, high levels of significance are maintained even when the elements of high involvement working are unbundled into three of its key aspects: company policies on information and knowledge sharing; individual participation in decision-making about task completion; and group responsibility for the work organisation (see Panel (c), Tables 6-9).

Of particular interest for this paper is the behaviour of the interaction terms. In general, this suggests - against the hypotheses that emerge from the literature reviewed above - that a high involvement work environment makes more of a difference to the skills exercised by nonstandard workers than it does to those employed on standard contracts. The skills gap between full-time and part-time jobs, for example, is significantly reduced in such a working environment. This result holds for problem-solving, planning, peer communication and checking skills. Similarly, the temporary-permanent skills gap is significantly reduced the greater the level of employee involvement for two out of four of these skills - problem-solving and checking. Even in the case of planning and peer communication skills, the interaction coefficients are positive but fail to reach levels of statistical significance (see Model 2, Panel (b), Tables 6-9).

The different aspects of high involvement working have varying degrees of explanatory power. Group working is most associated with a closure of the part-time/full-time skills gap for all four generic skills, the interaction terms are positive and significant. Individual 
involvement in decision-making comes next with a significant and positive interaction effect for three out of four generic skills, and company policies have the weakest connection of all. Nevertheless, the latter are associated with a significant closure of the gap as regards two out of four generic skills - the use of planning and peer communication skills. However, none of the three elements of high involvement working on their own are associated with a significant closure of the temporary-permanent skills gap (see Model 3, Panel (c), Tables 6-9).

To complete the analysis, we examine the associations insecurity has with non-standard work, high involvement workplaces and a combination of the two. The results are presented in Table 10. Model 1 reports the results without controls. This corroborates the bivariate finding that part-timers are significantly more optimistic than full-timers about retaining their current job, while temporary employees are significantly more pessimistic than those in permanent positions. However, the part-time result is not robust in the face of control variables. Their insertion wipes out completely the significance of the part-time coefficient, but does little to change the sign or strength of the positive association that temporary working has with insecurity (see Panel (a), Table 10). Put another way, the probability, for example, that a part-time worker feels that it is 'very likely' that they will lose their job in the next year is virtually identical to the probability that a full-time worker feels the same - in both cases, the probability is around 0.03. However, for temporary employees the probability is estimated to be 0.16 , significantly higher than for similarly placed employees on permanent contracts. Nevertheless, temporary employees in high involvement workplaces benefit most from the dampening effect that these environments have on the likelihood of job loss, although this result is not statistically significant (note the large but insignificant interaction coefficient in Model 3, Panel (b), Table 10). 
TABLE 10:

LIKELIHOOD OF JOB LOSS, NON-STANDARD JOBS AND HIGH INVOLVEMENT WORK SYSTEMS, 2001

\begin{tabular}{|c|c|c|c|}
\hline & Model 1 & Model 2 & Model 3 \\
\hline \multicolumn{4}{|l|}{ (a) Non-Standard Jobs } \\
\hline Part-Time Job & $\begin{array}{l}-0.2988^{* * *} \\
(0.0629)\end{array}$ & $\begin{array}{l}-0.0460 \\
(0.0772)\end{array}$ & $\begin{array}{l}-0.0417 \\
(0.0790)\end{array}$ \\
\hline Temporary Job & $\begin{array}{l}0.9862^{* * *} \\
(0.0823)\end{array}$ & $\begin{array}{l}1.0891^{* * *} \\
(0.0936)\end{array}$ & $\begin{array}{l}1.0504 * * * \\
(0.1004)\end{array}$ \\
\hline \multicolumn{4}{|c|}{ (b) High Involvement Work Systems } \\
\hline $\begin{array}{l}\text { High Involvement } \\
\text { Work Index }\end{array}$ & $\begin{array}{l}-0.2362^{* * *} \\
(0.0442)\end{array}$ & $\begin{array}{l}-0.2223 * * * \\
(0.0532)\end{array}$ & $\begin{array}{l}-0.2126^{* * *} \\
(0.0592)\end{array}$ \\
\hline $\begin{array}{l}\text { High Involvement } \\
\text { Work Index and Part- } \\
\text { Time Jobs }\end{array}$ & -- & -- & $\begin{array}{c}0.0207 \\
(0.1182)\end{array}$ \\
\hline $\begin{array}{l}\text { High Involvement } \\
\text { Work Index and } \\
\text { Temporary Jobs }\end{array}$ & -- & -- & $\begin{array}{l}-0.1588 \\
(0.1643)\end{array}$ \\
\hline \multicolumn{4}{|l|}{ (c) Model Parameters } \\
\hline Controls & Yes & Yes & Yes \\
\hline Pseudo R Squared & 0.0358 & 0.0607 & 0.0609 \\
\hline $\begin{array}{l}\text { Number of } \\
\text { Observations }\end{array}$ & 3817 & 3661 & 3661 \\
\hline
\end{tabular}

Notes:

1. This table reports the ordered probit results for each column. Column 1 reports a model without controls and simply comprising two dummy variables for part-time jobs and temporary jobs along with the high involvement work index (see text). Column 2 reports on the same model with a range of control variables added. The latter comprise dummy variables for gender, unionised workplace, public sector, ten regional locators, four establishment size categories, two workplace gender composition indicators, eight occupational groups, four levels of qualification held and twelve industrial groups. Age and age squared of respondents are entered as continuous variables. Column 3 adds two interaction terms to Model 2 in order to indicate whether or not the relationship non-standard working has with insecurity is modified by the presence of high involvement work practices, and if so in what way.

2. White-corrected standard errors are shown in parentheses. These are used in preference to conventional estimates of variance in order to provide robust tests of significance in the presence of heteroskedasticity.

3. $* * *=99 \%$ significant; $* *=95 \%$ significant $*=90 \%$ significant.

Source: 2001 Skills Survey. 


\section{Conclusion}

It has become almost commonplace to assume that non-standard work is 'inferior', 'peripheral' or 'atypical' - in short, sub-standard as regards terms and conditions of employment. Of particular interest to this paper is the assumption that non-standard jobs are lowly skilled and more precarious forms of employment than standard jobs with which they are compared. The high involvement work literature, on the other hand, tends to make little of these contractual distinctions and instead implies that the benefits associated with such environments are spread equally throughout the workforce. The paper addresses eight specific hypotheses that emerge from these often quite separate strands of literature on organisational flexibility. These hypotheses serve to frame and guide the analysis on which the paper is based.

The first hypothesis is that part-timers are in less skilled jobs than those on permanent contracts. The evidence here is overwhelmingly in support of this proposition. This finding is consistent across a range of skill measures extracted from the 2001 Skills Survey. On average, the skill demands of part-time jobs are significantly lower than those of full-time jobs: a wide range of activities commonly carried out at work are rated of lesser importance; qualifications required for entry are lower; training periods quicker; learning times shorter; and development opportunities narrower. Moreover, the picture remains remarkably stable irrespective of the 'skill' level at which comparisons are made. Furthermore, multivariate analysis suggests that this disadvantage persists for the generic skills of problem-solving, peer communication, checking and planning even when the impact of industry, occupation, gender and so on are controlled for.

However, we find far less support in the data for the second hypothesis, which suggests a link between part-time work and relatively high levels of insecurity. In fact, bivariate comparisons suggest the complete opposite with part-timers feeling significantly more secure in their jobs than full-timers. This result applies to a number of measures of insecurity including whether or not job loss is considered a possibility, the likelihood of such an event happening and the overall risk of job loss to which respondents are exposed. However, doubt is cast over the robustness of this initial finding when the data are subject to multivariate analysis. This suggests that levels of insecurity do not vary significantly between full-timers and part-timers. In other 
words, the aggregate differences between full-timers' and part-timers' exposure to job loss is largely accounted for by the over-representation of part-timers in relatively low insecurity industries and occupations (as captured by control variables) and their under-representation in high insecurity sectors. Nevertheless, even this analysis does not support the hypothesis that there is an association between insecurity and part-time working. We can, therefore, reject this proposition.

The paper presents considerable - though not overwhelming - support for the third hypothesis associating temporary working with low skill levels. According to all of the importance ratings of work activities, temporary employees are in significantly less demanding jobs than those on permanent contracts. Access to development opportunities and length of time needed to learn to do the job well also suggests that temporary workers are in a more disadvantaged position. However, differences in terms of the qualifications required for jobs and the training time needed to carry them out are minor and statistically insignificant. Part of the explanation may be found in the differential skill demands that different types of temporary work place upon jobholders. On both of these measures, we find that those on casual/seasonal/agency contracts are in jobs that require very low skill levels, but those whose contracts are of a fixed duration are in much more demanding roles. However, these results are based on small cell sizes and one implication of this finding is that much more information is needed about the differential experience and demands placed upon temporary workers according to the permanency of the connection with their current employer. Nevertheless, the regressions demonstrate that, on the whole, temporary workers are significantly less able to exercise a number of key generic skills at work.

The fourth hypothesis is that temporary workers suffer from relatively high levels of insecurity. This is borne out in both the bivariate and multivariate analyses. These consistently show that temporary workers are in less secure employment - their chances of job loss and the riskiness of their jobs are significantly higher than permanent workers. Temporary employees' pessimistic view of their chances of remaining in post for more than a year remains undiminished even when other factors such as the distribution of temporary employment by industry, occupation and so on are taken into account. 
In addition, the paper considers what, if any, mediating influence working in a high involvement environment has on these patterns. This theme forms the basis of the remaining four hypotheses the paper sets out to address. The literature suggests (rather than demonstrates) that certain skills are more likely than others to be associated with work organisations that empower workers to participate in decision-making, encourage them to work with others in the organisation and enhance their commitment to the organisation. Foremost among these are problem-solving, checking, planning and peer communication skills. The literature also suggests that feelings of insecurity are much reduced in such organisations. Our evidence demonstrates that both of these connections have considerable empirical validity. Furthermore, it shows that contrary to our fifth hypothesis - part-timers are likely to benefit more than permanent workers from the association that high involvement working has with these skills. The evidence also points to a similar finding for temporary workers, although this only holds for two out of the four skills examined. The data, therefore, provide mixed support for the seventh hypothesis, which suggests that high involvement work environments will make little difference to the skills content of temporary jobs.

The remaining two hypotheses, on the other hand, receive rather more support. The data analysis confirms that employment in a high involvement workplace makes little significant difference to the employment security of part-time employees as compared to those on full-time contracts (hypothesis six). However, the same employment environment lessens the chances of job loss for temporary workers, although the effect falls short of being statistically significant. It is, therefore, in line with our eighth and final hypothesis, which specifies that temporary and permanent workers feel the beneficial effect of high involvement on employment security equally.

The results of this paper have a number of important implications for policy-makers and researchers alike. The paper's main message for policy-makers seeking to promote a high skill and yet socially inclusive economy is that non-standard workers are, on the whole, relatively disadvantaged in terms of the skills they are called upon to exercise at work, the development opportunities they have and, in some cases, the security of their jobs. This finding is especially 
important in the light of European Union Directives on non-standard employment that are gradually being incorporated in UK labour law. The 1997 Part-time Work Directive came into force in 2000, the 1999 Fixed-term Work Directive is to due to take effect in July 2002 and a draft of the Temporary Agency Work Directive has recently been published (Financial Times, 6 and 21 March 2002). All aim to ensure that non-standard workers receive comparable treatment to those on permanent, full-time contracts in terms of pay, pensions, holidays and other benefits (including access to training and the opportunity of becoming a permanent member of staff under the draft fixed-term regulations that will take effect in 2002). Claims for equal treatment will have to be based on the grounds that the part-timer/fixed-term employee/agency worker is 'engaged in the same or broadly similar work' as someone employed by the same employer on a full-time/permanent basis. In this context, claims that work is comparable will rest on showing 'they have a similar level of qualification, skill and experience' (Stationery Office, 2000: clause 2(4)). Inevitably, the lower skill content of non-standard jobs - as evidenced in this paper - will, therefore, play a major role in adjudicating on whether, in fact, employers have unfairly treated non-standard workers.

The findings also have implications for government proposals to use some types of nonstandard employment as a means of helping individuals reconcile the competing demands of work and family life (Dex and Smith, 2000; Hogarth et al., 2000; Felstead et al., 2002). As from April 2003, employers will be obliged seriously to consider requests from parents for part-time work, compressed hours, flexitime and working at home (DTI, 2001; Financial Times, 22 November 2001). It will be important that these moves do not dampen the growth in skills overall nor increase the numbers of workers whose non-standard status is associated with relative disadvantage in terms of skills, development opportunities and employment security. The knockon effects of these legislative changes will have on the government's skills and inclusion agendas will, therefore, need to be taken into account when the government's work-life balance policies are reviewed - currently such an evaluation is due to take place three years after the 'right to flexible employment' legislation is implemented.

Nevertheless, the paper also shows that in some workplaces the skills and employment insecurity disadvantages faced by non-standard workers are far less pronounced than in others. 
These workplaces are characterised by greater openness, higher levels of employee participation and more of an emphasis on teamworking - what the literature refers to as high involvement work systems. Some of these elements are an integral feature of the Investors in People (IiP) programme (Alberga et al., 1996; Hoque, 2001), which in fact correlates very well with our high involvement work index. Promotion of IiP may, therefore, have as a by-product the effect of diminishing the disadvantages that non-standard workers often face. Strategies to push up the numbers of organisations recognised as Investors in People - currently standing at almost 25,000 and covering $36 \%$ of employees - could, in addition to promoting best practice in people development throughout the economy, help close the skills and development gaps that exist between full-timers and part-timers, and permanent and temporary workers (figures refer to February 2002, www.iipuk.co.uk/statisticsonthestandard/).

For researchers, the paper points to a number of avenues for further investigation. The paper highlights that more needs to be known about how some organisational forms are better able to use and develop the skills employees bring to the workplace than others. Advances have been made at a theoretical level as to why this might be so and survey data - including the results outlined here - are beginning to emerge to support the linkage. However, we still know comparatively little about the actual mechanisms involved - case study work will be required to illuminate these finer details. The results of this paper suggest that these case studies will need to pay particular attention to an examination of how these mechanisms vary between those working on different contractual terms. Another avenue for future research - and one that we intend to pursue - is to examine how far the growing use of high involvement working can account for the narrowing of the skills gap between part-timers and full-timers. Comparisons between 1986 and 2001 data, for example, suggest a consistent and gradual closing of the gap according to many skills measures. The results presented here suggest that changing work environments may be an explanatory factor behind this trend.

More generally, it is hoped that by bringing together the debates on non-standard employment and high involvement working, the paper has shown how the insights of one debate can provide useful and illuminating insights in the other. The challenge now is to ensure that these benefits are not lost and that future research is constructed with this crossover in mind. 


\section{Acknowledgements}

The 2001 Skills Survey was funded through a contract between the Department for Education and Skills and the Centre for Skills Knowledge and Organisational Performance (SKOPE) at the Universities of Oxford and Warwick. We are grateful to Ken Mayhew (Director of SKOPE) for his continuing support, to Rosa Fernandez for research assistance and to Francis Green, our co-researcher on the survey. Material from the Labour Force Surveys is Crown Copyright and has been made available by National Statistics (NS) through The Data Archive and has been used by permission. Neither NS nor The Data Archive bear any responsibility for the analysis or interpretation of the data reported here. We would like to thank David Ashton, Lesley Giles, Sally Walters and participants at the 2001 Skills Survey Seminar in Oxford on 28 February 2002 for their helpful and critical comments on an earlier version of this paper. However, the usual caveat applies. 


\section{References}

Alberga, T, Tyson, S and Parsons, D (1996) 'An evaluation of the Investors in People Standard', Human Resource Management Journal, 7(2): 47-60.

Appelbaum, E, Bailey, T, Berg, P and Kalleberg, A (2000) Manufacturing Advantage: Why High-Performance Work Systems Pay Off, Ithaca and London: Cornell University Press.

Arulampalam, W and Booth, A L (1998) 'Training and labour market flexibility: is there a tradeoff?', British Journal of Industrial Relations, 36(4), December: 521-536.

Ashton, D and Sung, J (2002) Supporting Learning for High Performance Working, Geneva: International Labour Organisation.

Atkinson, J (1984) 'Manpower strategies for flexible organisations', Personnel Management, 16(8), August: 28-31.

Batt, R (1999) 'Work organization, technology, and performance in customer service and sales', Industrial and Labor Relations Review, 52(4), July: 539-564.

Benders, J, Huijgen, F, Pekruhl, U and O'Kelly, K P (1999) Useful for Unused - Group Work in Europe, Dublin: European Foundation for the Improvement of Living and Working Conditions.

Booth, A L, Francesconi, M and Frank, J (2000) 'Temporary jobs: who gets them, what are they worth, and do they lead anywhere?', Institute for Social and Economic Research, University of Essex, Working Paper 2000-13.

Brown, C, Reich, M and Stern, D (1993) 'Becoming a high-performance work organization: the role of security, employee involvement and training', International Journal of Human Resource Management, 4(2), May: 247-275.

Burchell, B, Elliott, J, Rubery, J and Wilkinson, F (1994) 'Management and employee perceptions of skill', in Penn, R, Rose, M and Rubery, J (eds) Skill and Occupational Change, Oxford: Oxford University Press.

Burchell, B, Lapido, D and Wilkinson, F (2002) (eds) Job Insecurity and Work Intensification, London: Routledge.

Burgess, S and Rees, H (1996) 'Job tenure in Britain 1975-92', Economic Journal, 106(435): 334-344.

Bynner, J (1994) 'Skills and occupations: analysis of cohort members' self-reported skills in the 
fifth sweep of the National Child Development Study', Social Statistics Research Unit, City University mimeo.

Cappelli, P and Neumark, D (2001) 'Do "high-performance" work practices improve establishment-level outcomes?', Industrial and Labor Relations Review, 54(4), July: 737-775.

CBI (1994) Flexible Labour Markets: Who Pays for Training?, London: Confederation of British Industry.

Connell, J and Burgess, J (1998) 'Workforce and skill restructuring in Australia', International Employment Relations Review, 4(1): 39-55.

Cousins, C (1999) 'Changing regulatory frameworks and non-standard employment: a comparison of Germany, Spain, Sweden and the UK', in Felstead, A and Jewson, N (eds) Global Trends in Flexible Labour, London: Macmillan.

Cully, M, Woodland, S, O’Reilly, A and Dix, G (1999) Britain at Work: As Depicted by the 1998 Workplace Employee Relations Survey, London: Routledge.

Dex, S and McCulloch, A (1995) Flexible Employment: A Statistical Analysis, Manchester: Equal Opportunities Commission.

Dex, S and McCulloch, A (1997) Flexible Employment: The Future of Britain's Jobs, London: Macmillan.

Dex, S and Smith, C (2000) 'The nature and pattern of family-friendly employment policy in Britain', paper presented to the Family-Friendly Employment Seminar, Family Policy Studies Centre, Novartis Foundation, London, 6 November.

Dickerson, A and Green, F (2002) 'The growth and valuation of generic skills', SKOPE Working Paper, forthcoming.

DTI (2001) About Time: Flexible Working - Work and Parents Taskforce Report, London: Department of Trade and Industry http://www.workandparentstaskforce.gov.uk/flexworking_report.pdf).

Edwards, P and Wright, M (2001) 'High-involvement work systems and performance outcomes: the strength of variable, contingent and context-bound relationships', International Journal of Human Resource Management, 12(4), June: 568-585.

Eraut, M, Alderton, J, Cole, G and Senker, P (1998a) 'Development of knowledge and skills in employment', University of Sussex Institute of Education Research Report No 5. 
Eraut, M, Alderton, J, Cole, G and Senker, P (1998b) 'Learning from other people at work', in Coffield, F (ed.) Learning at Work, Bristol: the Policy Press.

Felstead, A and Ashton, D (2000) 'Tracing the link: organisational structures and skill demands', Human Resource Management Journal, 10(3), July: 5-21.

Felstead, A and Jewson, N (1999) (eds) Global Trends in Flexible Labour, London: Macmillan.

Felstead, A, Ashton, D and Green, F (2001) 'Paying the price for flexibility? Training, skills and non-standard jobs in Britain', International Journal of Employment Studies, 9(1), April: 2560.

Felstead, A, Gallie, D and Green, F (2002a) Work Skills in Britain, 1986-2001, London: Department for Education and Skills.

Felstead, A, Jewson, N, Phizacklea, A and Walters, S (2002b) 'Opportunity to work at home in the context of work-life balance', Human Resource Management Journal, 12(1): 54-76.

Felstead, A, Powell, M and Krahn, H (1999) 'Young and old at risk: comparative trends in "nonstandard" employment in Canada and the United Kingdom', International Journal of Manpower, 20(5): 277-296.

Gallie, D and White, M (1993) Employee Commitment and the Skills Revolution, London: Policy Studies Institute.

Gallie, D, White, M, Cheng, Y and Tomlinson, M (1998) Restructuring the Employment Relationship, Oxford: Oxford University Press.

Gallie, D, Felstead, A and Green, F (2002) 'Task discretion and participation', SKOPE Working Paper, forthcoming.

Gittleman, M, Horrigan, M and Joyce, M (1998) “"Flexible” workplace practices: evidence from a nationally representative survey', Industrial and Labor Relations Review, 52(1), October: 99-115.

Green, F (1999) 'Training the workers', in Gregg, P and Wadsworth, J (eds) The State of Working Britain, Manchester: Manchester University Press.

Green, F, Felstead, A and Burchell, B (2000) 'Job insecurity and the difficulty of regaining employment: an empirical study of unemployment expectations', Oxford Bulletin of Economics and Statistics, 62, (Special Issue), December: 855-883.

Gregg, P and Wadsworth, J (1995) 'A short history of labour turnover, job tenure, and job security, 1975-93', Oxford Review of Economic Policy, 11(1), Spring: 73-90. 
Gregg, P, Knight, G and Wadsworth, J (2000) 'Heaven knows I'm miserable now', in Heery, E and Salmon, J (eds) The Insecure Workforce, London: Routledge.

Guest, D E (1999) 'Human resource management - the workers' verdict', Human Resource Management Journal, 3(3): 5-25.

Guest, D E and Conway, N (1997) Employee Motivation and the Psychological Contract, London: Institute of Personnel and Development.

Hakim, C (1987) 'Trends in the flexible workforce', Employment Gazette, 95(11): 549-560.

Hogarth, T, Hasluck, C, Pierre, G with Winterbotham, M and Vivian, D (2000) Work-Life Balance 2000: Baseline Study of Work-Life Balance Practices in Great Britain - Summary Report, London: Department for Education and Employment.

Hoque, K (2001) 'All in all, it's just another plaque on the wall: the incidence and impact of the Investors in People standard', paper presented at the paper presented to the Second Meeting of the WERS98 User Group, National Institute of Economic and Social Research, 30 March.

Horrell, S, Rubery, J and Burchell, B (1989) 'Unequal jobs or unequal pay?', Industrial Relations Journal, 20(3), Autumn: 176-191.

Horrell, S, Rubery, J and Burchell, B (1994) 'Gender and skills', in Penn, R, Rose, M and Rubery, J (eds) Skill and Occupational Change, Oxford: Oxford University Press.

Kalleberg, A (2001) 'Organizing flexibility: the flexible firm in a new century', British Journal of Industrial Relations, 39(4), December: 479-504.

Kalleberg, A L, Rasell, E, Hudson, K, Webster, D, Reskin, B F, Cassirer, N and Appelbaum, E (1997) Nonstandard Work, Substandard Jobs: Flexible Work Arrangements in the US, Washington: Economic Policy Institute/Women's Research and Education Institute.

MacDuffie, J P (1995) 'Human resource bundles and manufacturing performance: organizational logic and flexible production systems in the world auto industry', Industrial and Labor Relations Review, 48(2), January: 197-221.

MacDuffie, J P and Kochan, T A (1995) 'Do U.S. firms invest less in human resources? Training in the world auto industry', Industrial Relations, 34(2), April: 147-168.

Millward, N, Forth, J and Bryson, A (1999) 'Changes in employment relations, 1980-1998', in Cully, M, Woodland, S, O'Reilly, A and Rix, G Britain at Work: As Depicted by the 1998 Workplace Employee Relations Survey, London: Routledge. 
NEDO (1986) Changing Working Patterns: How Companies Achieve Flexibility to Meet New Needs, London: National Economic Development Office.

Osterman, P (1995) 'Skill, training, and work organization in American establishments', Industrial Relations, 34(2), April: 125-146.

Osterman, P (2000) 'Work reorganization in an era of restructuring: trends in diffusion and effects on employee welfare', Industrial and Labor Relations Review, 53(2), January: 179196.

Rix, A, Davies, K, Gaunt, R, Hare, A and Cobbold, S (1999) 'The training and development of flexible workers', Department for Education and Employment Research Report No 118.

Rosenberg, S and Lapidus, J (1999) 'Contingent and non-standard work in the United States: towards a more poorly compensated, insecure workforce', in Felstead, A and Jewson, N (eds) Global Trends in Flexible Labour, London: Macmillan.

Stationery Office (2000) The Part-time Workers (Prevention of Less Favourable Treatment) Regulations, Statutory Instrument 2000 No. 1551, London: The Stationery Office.

TUC (1995) Training in Flexible Labour Markets: A TUC Submission to the CBI, London: Trades Union Congress.

Walton, R E (1985) 'From control to commitment in the workplace', Harvard Business Review, 65: 77-84.

Warren, T (2000) 'Women in low status part-time jobs: a class and gender analysis', Sociological Research Online, 4(4), http://www.socresonline.org.uk/4/4/warren.html

White, M (1999) 'Performance, equality and staff development', Human Resource Management Journal, 9(1): 47-54.

Whitfield, K (2000) 'High-performance workplaces, training, and the distribution of skills', Industrial Relations, 39(1), January: 1-25.

Wood, S (1999a) 'Getting the measure of the transformed high-performance organization', British Journal of Industrial Relations, 37(3), September: 391-417.

Wood, S (1999b) 'Human resource management and performance', International Journal of Management Reviews, 1(4): 367-413. 